\title{
Distribution and composition of dissolved extracellular polymeric substances (EPS) in Antarctic sea ice
}

\author{
Graham J. C. Underwood ${ }^{1, *}$, Susanne Fietz ${ }^{1,4}$, Stathys Papadimitriou², \\ David N. Thomas ${ }^{2}$, Gerhard S. Dieckmann ${ }^{3}$ \\ ${ }^{1}$ Department of Biological Sciences, University of Essex, Wivenhoe Park, Colchester, Essex CO4 3SQ, UK \\ ${ }^{2}$ Ocean Sciences, College of Natural Science, Bangor University, Menai Bridge, Anglesey LL59 5AB, UK \\ ${ }^{3}$ Alfred Wegener Institute for Polar and Marine Research, Am Handelshafen 12, 27570 Bremerhaven, Germany \\ ${ }^{4}$ Present address: Institute of Environmental Science and Technology (ICTA), Universitat Autònoma de Barcelona, \\ 08193 Bellaterra, Spain
}

\begin{abstract}
Concentrations and chemical composition of carbohydrates in dissolved organic carbon (DOC) and in extracellular polymeric substances (EPS) from brines, ice cores, gap layers in sea ice and associated surface waters were determined during 2004 and 2006 in the Weddell Sea, Antarctica. High levels of spatial heterogeneity were a common feature in these habitats, with DOC concentrations ranging from 45 to $669 \mu \mathrm{mol} \mathrm{C} \mathrm{kg}{ }^{-1}$. The highest concentrations of DOC and carbohydrate were measured in bulk sea-ice brines. Concentrations of dissolved carbohydrate ( $>8 \mathrm{kDa}$ in size) varied between 31 and $255 \mu \mathrm{mol} \mathrm{C} \mathrm{kg}^{-1}$ (glucose-carbon equivalent), and consisted of ca. $40 \%$ of the DOC in melted ice cores, and 10 to $20 \%$ of the DOC in ice brines. Dissolved carbohydrate and DOC concentrations were significantly correlated to chl a. Carbohydrate present as EPS (determined by selective alcohol precipitation) made up > $>8 \%$ of dissolved carbohydrates in all sea ice habitats. There were significant differences in concentration and relative importance of different EPS size fractions, and in the uronic acid content and monosaccharide composition (especially for glucose contribution), of different sea ice habitats, in relation to chl a concentrations, and between the 2 sampling cruises. High algal biomass was associated with greater relative abundance of glucose-rich EPS. Fractionation of EPS on the basis of solubility found that the least soluble EPS fraction contained substantial amounts of uronic acids and higher proportions of mannose, xylose, fucose and rhamnose than the more soluble EPS fractions. This relatively insoluble EPS fraction had characteristics that could contribute to a hydrophobic and structured microenvironment surrounding cells. EPS thus modify the local environment in sea ice brine channels, and form a chemically diverse source of DOC to the water column upon ice melt.
\end{abstract}

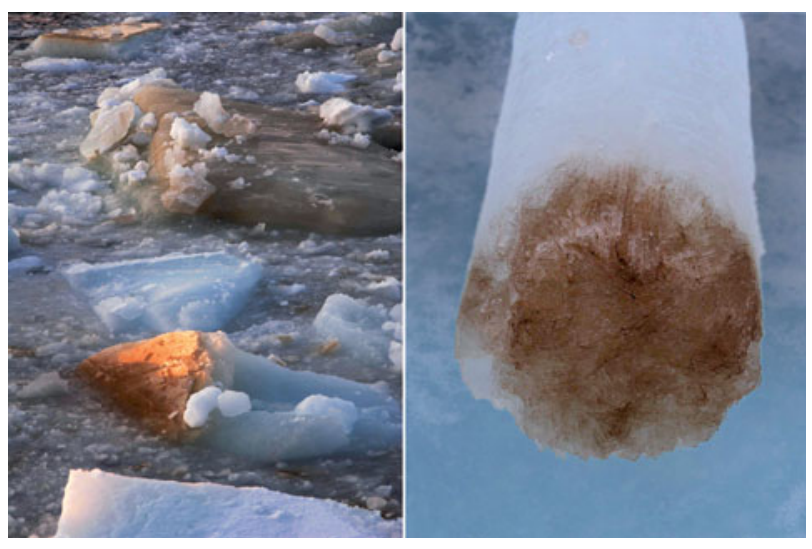

Overturned ice floes and detail of an ice core from the Weddell Sea showing extensive growth of sea-ice diatom assemblages.

Photo: David N. Thomas

KEY WORDS: Extracellular polymeric substances . EPS · Dissolved organic carbon · DOC · Carbohydrates · Microalgae $\cdot$ Sea ice $\cdot$ Brine $\cdot$ Antarctic

Resale or republication not permitted without written consent of the publisher

\section{INTRODUCTION}

Sea ice in the Arctic and Southern Oceans, as well as in the seasonally ice-covered sub-Arctic seas, can contain high standing stocks of microalgae and bacteria that provide a food resource for numerous protozoan and metazoan consumers (Thomas \& Dieckmann 2002, 2010). Sea ice consists of a matrix of ice permeated by a channel and pore system that contains brine, with a 
volume fraction and salinity dependent on the temperature of the ice (Petrich \& Eicken 2010). Consequently, temperature gradients through an ice floe correspond to gradients of brine volume and salinity. The densest biological assemblages are frequently found on the peripheries of ice floes near the ice-water interface, and are often referred to as bottom assemblages (Arrigo et al. 2008). High biological activity is also often observed around internal sea ice surfaces formed as a result of freeze-thaw processes, such as those that develop near surface gap layers (Haas et al. 2001, Ackley et al. 2008, Papadimitriou et al. 2009). Bottom and surface gap sea ice assemblages flourish on the resupply of inorganic nutrients from the underlying seawater, which can limit the productivity of internal ice habitats (Kennedy et al. 2002, Kattner et al. 2004). Associated with the dense biological assemblages in sea ice are high concentrations of dissolved organic matter (DOM), both dissolved organic carbon (DOC) and dissolved organic nitrogen (DON; Thomas et al. 1998, Carlson et al. 2000, Herborg et al. 2001, Papadimitriou et al. 2007, 2009). This DOM is present at concentrations several factors higher than would result merely from the conservation of surface seawater DOM in the brine which forms as sea water freezing. The major producers of this DOM are the algae that grow on the ice surfaces and within the brine channels (Krembs \& Engel 2001, Meiners et al. 2003, 2008). The nature of sea ice DOM has been poorly described to date, although several studies have demonstrated that it is rich in carbohydrates originating in the extracellular polymeric substances (EPS) released by sea ice bacteria and microalgae (reviewed by Krembs \& Deming 2008).

EPS are complex organic macromolecules that bind microbial aggregates together and include lipids, nucleic acids, proteins and carbohydrates. EPS exist in natural conditions in an equilibrium of solubility and forms. Individual polymers alter their properties as external conditions vary, for example condensing into gels under changing salinity or ion concentrations, adsorbing onto existing flocs, and forming colloidal 'sponge-like' gels that contain dissolved material within the matrix. EPS compounds are also modified by abiotic (e.g. hydrolysis, photolysis) or biotic changes (e.g. microbial modification). EPS are operationally defined to be those molecules that precipitate in a polar solvent (usually $70 \%$ ethanol [EtOH]; Decho 1990, Underwood \& Paterson 2003). Carbohydrates are the most abundant component, generally representing 40 to $95 \%$ of the EPS in marine autotrophic biofilms (Wingender et al. 1999, Underwood \& Paterson 2003). The carbohydrate pool of EPS in marine habitats consists of mono- and polysaccharides of varying molecular complexity, ranging from short-chain oligosaccha- rides (less than 10 monomer units), low molecular weight (LMW) to long-chain (from 40 up to many 1000s of monomer units), high molecular weight (HMW) compounds (Decho 2000, Underwood \& Paterson 2003, Bellinger et al. 2005). The production of microalgal EPS is widespread in aquatic systems, with mechanisms ranging from an imbalance between photosynthesis and cell growth (the carbon overflow hypothesis) to specific roles in the physiology or ecology of the producer organism, such as stabilisation, attachment and motility (Smith \& Underwood 1998, Decho 2000, Staats et al. 2000, Underwood \& Paterson 2003).

Marine diatoms are known to produce a number of different EPS, varying in molecular size, chemical composition and solubility, depending on the nutrient status, growth phase, behaviour and photosynthetic activity of the cells (Wustman et al. 1997, Underwood et al. 2004, Apoya-Horton et al. 2006). Some EPS are secreted as mucilaginous slime coating the cells (Underwood \& Paterson 2003), and this protective cover is thought to play a key role in microbial defence against harmful physico-chemical conditions, especially as cryoprotection and as a barrier against hypersalinity (Krembs et al. 2002, Krembs \& Deming 2008).

Several studies have reported large variability of EPS abundance and properties in sea ice habitats. This variability may be due to (1) large-scale differences between Arctic (Krembs et al. 2001, 2002, Meiners et al. 2003) and Antarctic sea ice (Herborg et al. 2001), (2) small-scale habitat characteristics (Herborg et al. 2001, Kattner et al. 2004), such as steep nutrient gradients from depletion in the interior of ice floes to replenished stocks near the ice-water interface (Meiners et al. 2003), (3) seasonality in productivity (Thomas et al. 1998), and (4) algal or bacterial species diversity (Mancuso Nichols et al. 2005). Most studies of sea ice EPS to date have investigated changes in the concentrations of total carbohydrate, and it is not known to what extent the characteristics of EPS differ within sea ice habitats. However, the composition and structure of the extracellular mucilage is hypothesised to greatly affect the protective properties of EPS against stressful micro-environmental changes (Krembs \& Deming 2008). The ability of an EPS to function as a protective agent for cells is related to its size and solubility, the composition of the polysaccharide chains, and the chemical characteristics of the monosaccharide component and their associated linkages. Unfortunately, many of the detailed analytical techniques needed to determine chemical structure require substantial amounts of purified material, which cannot easily be obtained from natural environments. Quantitative EPS analyses suitable for field samples that provide some structural and chemical composition information need to be developed to help understand the potential role 
of EPS in sea ice biogeochemistry and in microbial survival, especially given the extreme conditions of salinity and temperature faced by sea ice organisms.

Sea ice is a physically, chemically and biologically dynamic medium, with limited accessibility and considerable spatial and temporal heterogeneity in both the horizontal and the vertical dimensions. In comparison to other aquatic environments, e.g. marine biofilms, our understanding of the distribution and production of EPS in sea ice is sparse (Krembs \& Deming 2008). The majority of studies characterising the distribution of sea ice EPS are from the Arctic (Krembs \& Engel 2001, Meiners et al. 2003, 2008, Riedel et al. 2006, 2007a,b, 2008, Collins et al. 2008), and were done by measuring transparent exopolymer particles (TEP) using the alcian blue method of Passow \& Alldredge (1995) that stains acid polysaccharides. This method potentially underestimates the total EPS concentration due to the specificity of the alcian blue staining technique used and because it measures the particulate EPS that is caught on a filter. Alternative methods for EPS determination, developed to study intertidal diatom biofilms (Underwood \& Paterson 2003), fractionate EPS present in aqueous samples by precipitation in varying concentrations of alcohol and quantification of neutral and acidic sugars in the precipitates. Polymer solubility depends on chain length, composition and branching, the solvent used, and molecular weight. In a diluted polar solvent, the most insoluble polymer precipitates first, roughly indicating higher molecular weight and branching, with more soluble EPS precipitating at higher solvent concentrations. (Aspinall 1982, Underwood et al. 2004). These different EPS fractions therefore contain both LMW EPS material that can be readily utilised by heterotrophic bacteria, as well as more recalcitrant fractions (Hofmann et al. 2009). Isolating EPS using these approaches presents new information on the dissolved EPS pool in sea ice, complementing the existing data on particulate or total EPS reported in previous studies. Such characterisation of the distribution and composition of dissolved EPS in sea ice is a necessary step to understanding its role in the biological assemblages living within and on the ice.

The aim of this study was to investigate the temporal and spatial distribution and compositional changes of dissolved EPS in sea ice in the Weddell Sea, in relation to overall DOC concentrations. We hypothesised that if EPS play a role in the cryoprotection of cells, the contribution of larger, more complex EPS to the dissolved DOC pool would increase with decreasing temperatures and increasing salinity. To this end, we determined the concentration and composition of dissolved EPS using the above-mentioned fractionation technique in first- and second-year Antarctic sea ice. We also determined the concurrent concentrations of DOC and chlorophyll a ( $\mathrm{chl} \mathrm{a}$ ) as proxies for the biomass of the biological assemblages in our study locations, which included different sea ice habitats, such as surface, internal, and bottom sea ice communities. The samples were collected from these different compartments of the sea ice system, i.e. bulk sea-ice cores, internal brines and water from seawater-infiltrated surface gap layers in sea ice (gap waters). The samples were collected during 2 cruises to the Weddell Sea, Antarctica, in December 2004 (ISPOL) and September to October 2006 (WWOS), thus encompassing contrasting sea ice conditions and types during 2 important transitional periods in the physics, chemistry and biology of the system, i.e. from spring to summer within the constraints of a single ice floe (ISPOL) and from winter to spring over several ice floes covering a large part of the northwestern Weddell Sea (WWOS).

\section{MATERIALS AND METHODS}

Study site. The initial part of the study was conducted in the transition from spring to summer during the interdisciplinary field experiment Ice Station Polarstern (ISPOL; Hellmer et al. 2006). During the experiment, the physical and biogeochemical properties of a $10 \times 10 \mathrm{~km}$ (initial dimensions) ice floe were monitored. The ISPOL floe was located at approximately 67 to $68^{\circ} \mathrm{S}$ and $55^{\circ} \mathrm{W}$ in the western Weddell Sea, where it was drifting in a northerly direction. This initial part of the current study represents first- and second-year ice from the structurally heterogeneous ISPOL floe (Papadimitriou et al. 2007, Haas et al. 2008). Details of the physical and chemical features of the floe have been reported elsewhere (Papadimitriou et al. 2007, 2009, Haas et al. 2008, Lannuzel et al. 2008). Briefly, the floe consisted of allochthonous second-year ice (200 to $250 \mathrm{~cm}$ thick, $80 \mathrm{~cm}$ snow cover) and first-year ice (150 to $180 \mathrm{~cm}$ thick, $30 \mathrm{~cm}$ snow cover), as well as autochthonous first-year ice $(80 \mathrm{~cm}$ thick). Internal brines from the thick first-year ice were found to contain a contingent of heterotrophic (ciliates, dinoflagellates and small aplasticid flagellated species) and autotrophic protists (flagellated prasinophytes, dinoflagellates and diatoms; Papadimitriou et al. 2007). In the gap waters in the surface of the thick first-year and second-year ice parts of the floe, diatoms and the prymnesiophyte Phaeocystis were the dominant autotrophic protists, with very small contributions by small heterotrophic ciliates and bacterivorous flagellates (Papadimitriou et al. 2009). The geochemical composition of both internal brines and surface gap waters exhibited a strong autotrophic signature (e.g. elevated $\mathrm{pH}$, dissolved molecular oxygen accumulation and re- 
duced concentrations of dissolved inorganic carbon and major dissolved nutrients), suggesting an active and dominant autotrophic assemblage (Papadimitriou et al. 2009).

The second part of the study was conducted in the transition from winter to spring during the Winter Weddell Outflow Study (WWOS) on board the German icebreaker RV 'Polarstern' (Lemke 2009). The cruise track comprised discrete ice stations in the north and northwestern Weddell Sea, from the South Orkney Islands over the South Orkney Plateau and South Scotia Ridge to the continental shelf of the north-eastern Antarctic Peninsula near the Larsen B ice shelf via the Powell Basin. We have no information on the taxonomic composition of the biological assemblages at the sampled ice floes, but preliminary biogeochemical observations from 14 of the 22 WWOS ice stations were reported by Meiners et al. (2009) and indicated a moderately active autotrophic community in the transition from spring to summer.

Field sampling. All measurements described here were obtained from opportunistically selected samples collected from (1) the aqueous phase of random flooded parts of the ice floe surface (surface layer samples) and of 2 spatially separate gap layers located within the top 10 to $30 \mathrm{~cm}$ of the ISPOL floe; (2) internal sea ice brines collected with the sackhole sampling technique; and (3) bulk sea ice from melted $10 \mathrm{~cm}$ thick ice core segments (for a discussion of the full ISPOL data set, see Papadimitriou et al. 2007, 2009). The sackhole sampling technique allows internal sea ice brine to percolate into bore holes (sackholes) drilled with the stainless steel corer (Kovacs, $14 \mathrm{~cm}$ internal diameter) to variable depth $(20$ to $60 \mathrm{~cm}$ ) below the ice surface following snow removal. Hence, data from sackhole samples refer to concentrations measured directly in sea ice brines. Ice cores in ISPOL were collected using a Kovacs Mark II stainless steel ice corer (9 cm internal diameter), and a Kovacs $14 \mathrm{~cm}$ internal diameter corer during WWOS, immediately sectioned (into $10 \mathrm{~cm}$ sections) and placed directly in acid-clean plastic containers, and melted (without additional liquid) in the dark at $4^{\circ} \mathrm{C}$ in the onboard laboratory. All samples were then filtered through pre-combusted GF/F filters (Whatman, $0.7 \mu \mathrm{m}$ ), and filters and filtrates were stored at $-20^{\circ} \mathrm{C}$ until further analysis in the home laboratory. Values derived from the melted ice core samples were converted into data for sea-ice brine using bulk sea ice porosity, salinity and temperature (see 'Temperature and salinity measurements'), and termed bulk sea-ice brine.

Chlorophyll, DOC and nutrient analysis. The chl a and phaeopigment a concentrations on the filters were determined on a Turner Designs TD-700 fluorometer following the method of Evans et al. (1987). The DOC concentrations were determined by high temperature combustion on an MQ 1001 TOC Analyzer (Qian \& Mopper 1996), while the major dissolved inorganic nutrients were determined using standard colorimetric or fluorometric methodology as described in detail by Papadimitriou et al. (2007).

Carbohydrate, uronic acid and protein analysis. The field samples were thawed and split into 4 equal aliquots of approximately 30 to $50 \mathrm{ml}$ (ISPOL) or 75 to $100 \mathrm{ml}$ (WWOS). High salt concentrations interfere with the carbohydrate assay, so aliquots were dialysed to a final sample $\mathrm{S}<1$ for between 3.5 and $5.5 \mathrm{~h}$, depending on salinity (S), through 8 to $10 \mathrm{KDa}$ dialysis tubing (VWR) in 21 flasks with moderate stirring using Milli$\mathrm{Q}^{\odot}$ water. The desalted samples were freeze-dried and stored at $-20^{\circ} \mathrm{C}$ until further analysis. Desalted dry samples were re-dissolved in $3.4 \mathrm{ml}$ Milli- $\mathrm{Q}^{\odot}$ water, thereby being concentrated by approximately a factor of 12 (ISPOL) and 26 (WWOS) relative to the initial sample volume. The re-dissolved samples were then divided into 4 subsamples, $1(0.4 \mathrm{ml})$ for the determination of total carbohydrates (TCHO) and $3(1.0 \mathrm{ml})$ for size-fractionated EPS (see scheme in Fig. 1). Because all samples were dialysed to remove salt before carbohydrate analysis, some of the LMW material present in the samples was lost. Dialysis with an 8 to $10 \mathrm{KDa}$ cutoff membrane will retain polysaccharides larger than 20 monosaccharide units. It is not possible to determine this loss exactly, because no measure of concentration before dialysis was possible, due to the high salt concentrations. Size fractionation on desalted material was conducted by precipitation in a polar solvent gradient of 30,50 , and $70 \mathrm{w} / \mathrm{v}$ ethanol $(\mathrm{EtOH})$ overnight at $4{ }^{\circ} \mathrm{C}$ (Fig. 1). The precipitates of the 3 size-fractionated (i.e. solvent strength fractionated) subsamples were each recovered by centrifugation $(3200 \times g, 15 \mathrm{~min})$ and were completely dried and each re-dissolved in $0.65 \mathrm{ml}$ Milli- $\mathrm{Q}^{\odot}$ water for the determination of carbohydrate $(0.4 \mathrm{ml})$ and uronic acid $(0.25 \mathrm{ml})$ concentration.

The carbohydrate concentration of the TCHO and the re-dissolved EPS fractions (see EPS size fractionation, Fig. 1) was determined using the phenol-sulphuric acid assay (Dubois et al. 1956, Smith \& Underwood 1998), modified for small volumes. Glucose was used as a standard, and, hence, the carbohydrate concentration is reported as glucose-carbon equivalents. Uronic acids were determined in the $0.25 \mathrm{ml}$ size-fractionated samples using the standard carbazole assay (Bitter \& Muir 1962, Bellinger et al. 2005). Glucuronic acid was used as standard, and all uronic acids are therefore expressed as glucuronic-carbon equivalents. Protein analysis was carried out in all samples after desalting (dialysis) using a BioRad ${ }^{\circledR}$ Lowry standard kit for the ISPOL samples. All readings except one were below the detection limit $\left(1 \mathrm{\mu g} \mathrm{ml}^{-1}\right)$. We therefore assumed 


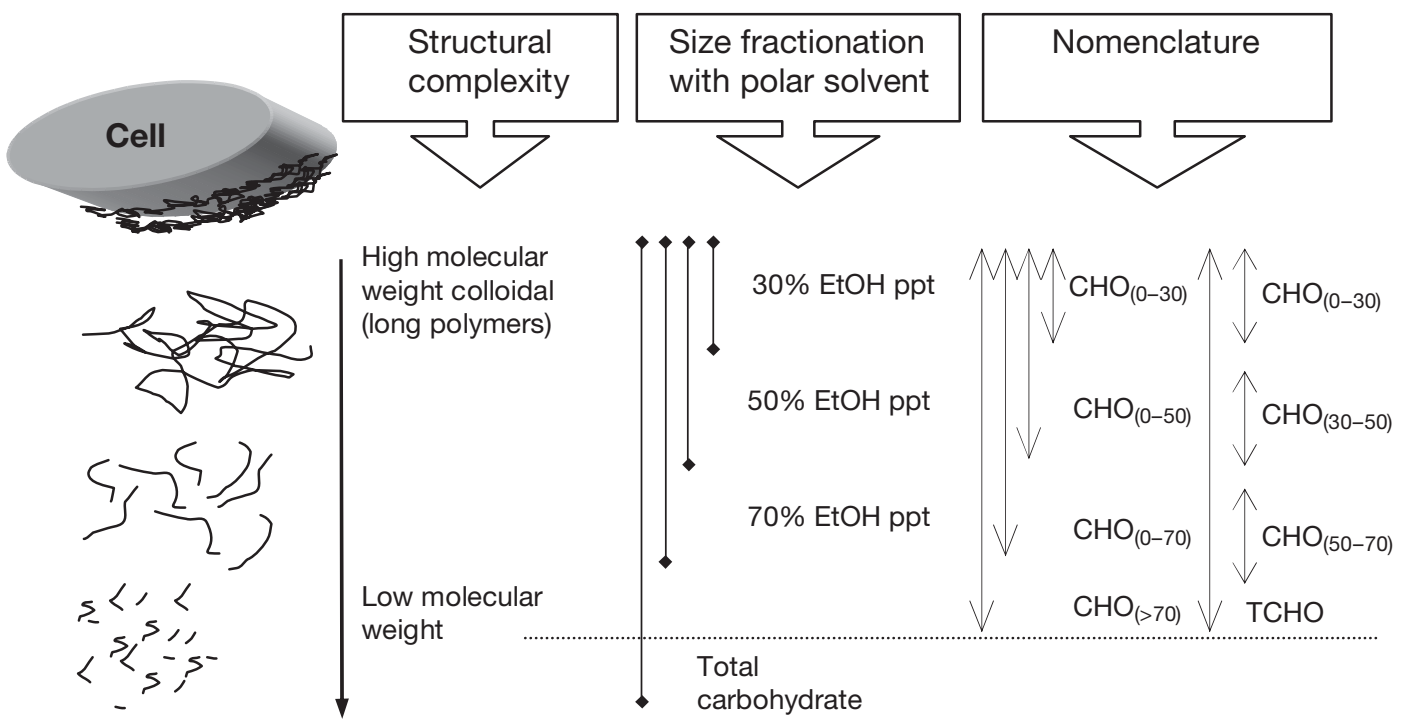

Fig. 1. Diatom extracellular polymeric substances (EPS) and size fractionation by solvent precipitation (ethanol, EtOH ppt) and nomenclature overview. Total carbohydrate (TCHO) refers to non-fractionated samples. $\mathrm{CHO}_{(0-30)}, \mathrm{CHO}_{(0-50)}$ and $\mathrm{CHO}_{(0-70)}$ refer to the respective size fractions. Dotted line indicates notional dialysis cut off at $8 \mathrm{KDa}$. See 'Materials and methods' for more details

that proteins were minor components in the EPS of our sample sets.

The neutral monosaccharide composition was determined on separate desalted aliquots following sample preparation based on the protocol of Wustman et al. (1997), modified by Bellinger et al. (2005). The carbohydrates in the dried TCHO and EPS-fractionated samples were hydrolysed with $200 \mu \mathrm{l} 2 \mathrm{M}$ trifluoroacetic acid at $100^{\circ} \mathrm{C}$ for $3 \mathrm{~h}$. This step was followed by drying at $40^{\circ} \mathrm{C}$ under a clean nitrogen stream. The monosaccharide mixture was saponified for $90 \mathrm{~min}$ with $50 \mu \mathrm{l} 1 \mathrm{M}$ ammonia and reduced to the corresponding alditols using $500 \mu \mathrm{l}$ of sodium borohydratedimethyl sulphoxide reagent. This latter reaction was quenched with $50 \mu \mathrm{l}$ acetic acid after 90 min incubation at $40^{\circ} \mathrm{C}$. The alditols were then acetylated with $100 \mu \mathrm{l}$ 1-methylimidazole and $1.0 \mathrm{ml}$ acetic anhydride. The acetylation was quenched after a 10 min incubation with $2.5 \mathrm{ml}$ Milli- $\mathrm{Q}^{\odot}$ water. The alditol acetates were extracted with $500 \mu \mathrm{l}$ dichloromethane, and the extract was transferred after a 10 to $20 \mathrm{~min}$ phase separation. The extract was then dried at $40^{\circ} \mathrm{C}$ under clean nitrogen and stored at $-25^{\circ} \mathrm{C}$ until analysis. The dried extracts were redissolved in $100 \mu \mathrm{l}$ dichloromethane, and $3 \mu$ aliquots were injected into a Finnigan Trace GC Ultra DSQ quadrupole gas chromatographmass spectrometer (GC-MS). Separation was carried out through an RT-2330 column with helium as the gas carrier $\left(1 \mathrm{ml} \mathrm{min}^{-1}\right)$ with a temperature gradient of $65^{\circ} \mathrm{C}$ for $0 \mathrm{~min}$, increasing by $8^{\circ} \mathrm{C} \mathrm{min}^{-1}$ to $240^{\circ} \mathrm{C}$ for $2 \mathrm{~min}$, then increasing by $4^{\circ} \mathrm{C} \mathrm{min}^{-1}$ to $250^{\circ} \mathrm{C}$ for $10 \mathrm{~min}$. The monosaccharides were identified according to their retention time and mass spectra, and were quantified using rhamnose, fucose, ribose, arabinose, xylose, mannose, galactose, glucose and inositol as standards that underwent the same hydrolysation and acetylation procedure. Reproducibility of replicate standards was within $1 \%$. Inositol was added as an internal standard to all samples to check for the extent of loss during the preparation process. The very small sample weights obtained from the sea ice samples meant that there was not enough material to quantify total sugar content within the same sample before derivitisation. Therefore, the monosaccharide data are presented as relative abundance (\% weight) of the total analysed fraction.

Nomenclature. The term 'carbohydrate' refers to the compounds determined using the modified Dubois assay used here and includes neutral sugars, as well as acidic carbohydrates. The term 'uronic acids' refers only to the acidic carbohydrates assessed by the carbazole assay. 'TCHO' describes the concentration of dissolved material in the unfractionated samples after dialysis. TCHO therefore measures EPS-carbohydrate compounds (those molecules that will precipitate in $70 \%$ EtOH) and non-EPS carbohydrates (i.e. those fractions that do not precipitate in $70 \% \mathrm{EtOH}$, but are larger than 8 to $10 \mathrm{KDa}$ ). We used 3 different $\mathrm{EtOH}$ concentrations for precipitation of EPS. $\mathrm{CHO}_{(0-30)}$ refers to the carbohydrate fraction precipitated by $30 \% \mathrm{EtOH}$. $\mathrm{CHO}_{(0-50)}$ and $\mathrm{CHO}_{(30-50)}$ refer to the EPS-carbohydrates precipitated by $50 \% \mathrm{EtOH}$ and to the fraction of material precipitated by $50 \%$ EtOH minus the fraction precipitated by $30 \%$ EtOH, respectively. $\mathrm{CHO}_{(0-70)}$ Correspondingly refers to the EPS-carbohydrates precipitated by $70 \% \mathrm{EtOH}$, and $\mathrm{CHO}_{(50-70)}$ refers to $\mathrm{CHO}_{(0-70)}$ 
minus $\mathrm{CHO}_{(0-50)}$ (Fig. 1). Solubility therefore increases from $\mathrm{CHO}_{(0-30)}$ to $\mathrm{CHO}_{(50-70)}$. Those compounds that do not precipitate in $70 \% \mathrm{EtOH}$ are considered nonEPS carbohydrates $\left(\mathrm{CHO}_{>70}\right)$ with the lowest molecular weight (Underwood \& Paterson 2003).

Temperature and salinity measurements. Temperature $\left(T,{ }^{\circ} \mathrm{C}\right)$ was measured in situ with a calibrated $\mathrm{K}$-Thermocouple probe on a HANNA Instruments thermometer (HI93530). Salinity (S) was measured at laboratory temperature $\left(17\right.$ to $\left.22^{\circ} \mathrm{C}\right)$ using a portable conductivity meter (SEMAT Cond 315i/SET) with a WTW Tetracon 325 probe. Brine $\mathrm{S}\left(\mathrm{S}_{\mathrm{b}}\right)$ was measured directly in sackhole brines after appropriate dilution with distilled water for $S_{b}>70$, while downcore $S_{b}$ was estimated from the in situ measured bulk sea-ice $T$ (Petrich \& Eicken 2010) as

$$
\mathrm{S}_{b}=1000\left(1-\frac{54.11}{T}\right)^{-1}
$$

The bulk sea-ice porosity, expressed as $\mathrm{V}_{\mathrm{b}} / \mathrm{V}=$ fraction of brine volume per total ice volume, was calculated from the measured bulk sea-ice $\mathrm{S}$ and in situ $T$ using the equations of Cox \& Weeks (1983) and Leppäranta \& Manninen (1988). Due to the temperature effect on volume owing to the large difference between the in situ temperature in sea ice and that of sample processing in laboratory conditions (e.g. solute analysis $T=17$ to $25^{\circ} \mathrm{C}$ ), in line with previously published work (Papadimitriou et al. 2004, 2007, 2009, Meiners et al. 2009), all concentrations are reported on a per kg solution (mass) basis $\left(\mathrm{C}_{\text {mass }}\right)$ after conversion of the measurements on a per unit volume basis $\left(\mathrm{C}_{\mathrm{vol}}\right)$ as

$$
\mathrm{C}_{\text {mass }}=\frac{\mathrm{C}_{\mathrm{vol}}}{\rho^{\prime}}
$$

where $\rho^{\prime}=$ sample density at the temperature of sample processing. The density of melted sea ice $\left(\rho_{\text {melt }}^{\prime}\right)$, brine $\left(\rho_{b}^{\prime}\right)$ and gap waters $\left(\rho_{\text {gap }}^{\prime}\right)$ in laboratory conditions was calculated by extrapolation of the equation of state for seawater reported by Millero \& Poisson (1981) to the sample salinity because the major ionic composition of sea-ice derived solutions reflects physical modification of that of oceanic water. The concentrations measured in melted bulk sea-ice were further converted on a per unit mass of brine for in situ $T$ conditions as

$$
\mathrm{C}_{\text {mass }}=\frac{\left(\frac{\mathrm{C}_{\text {vol }}}{\rho_{\text {melt }}^{\prime}}\right) \rho_{\text {bulk ice }}}{\left(\mathrm{V}_{\mathrm{b}} / \mathrm{V}\right) \rho_{\mathrm{b}}}
$$

where $V_{b} / V$ is the relative brine volume (bulk sea-ice porosity) as before, and $\rho_{\text {bulkice }}$ and $\rho_{\mathrm{b}}$ are the bulk sea-ice and brine densities, respectively, at in situ $T$ calculated as in Cox \& Weeks (1983), using the temper- ature polynomial functions of Cox \& Weeks (1983) and Leppäranta \& Manninen (1988).

Statistical analysis. Significant differences between sample types (e.g. sackholes, surface layers) and between the data sets from the 2 separate cruises were determined using analysis of variance (ANOVA, with Tukey post hoc tests). Where data showed significant deviation from normality, log-transformation was used. Pearson's correlation analysis was used to investigate relationships between DOC and carbohydrate concentrations and chl $a$, and the relative contribution of different fractions and relative abundance of monosaccharides in EPS fractions were used to determine significant correlation and significant differences between sample sets. Analyses were conducted on SPSS ${ }^{\circledR}$ 15.01 and Minitab v. 13.1. All statistically significant differences quoted were at $\mathrm{p} \leq 0.05$.

\section{RESULTS}

\section{DOC pool size and TCHO composition}

There were significant differences in the concentrations of DOC and the concentrations of different carbohydrate fractions (ANOVA, $F=2.4$ to 24.8 , all $\mathrm{p} \leq 0.05$ ) between the surface layers, gap waters, bulk sea-ice brines and sackhole brines examined in this study (Table 1). The DOC concentrations in bulk sea-ice brine were higher than those determined directly in the companion sackhole brine samples (Table 1). The average DOC concentration in both bulk sea-ice and sackhole brine was higher $\left(>178 \mu \mathrm{mol} \mathrm{kg}{ }^{-1}\right.$, Table 1) than that in surface oceanic water $\left(51 \pm 15 \mu \mathrm{mol} \mathrm{kg}{ }^{-1}\right.$, measured during ISPOL; Papadimitriou et al. 2007). Average DOC concentrations in the WWOS multiple ice floes were significantly higher than those measured in the ISPOL ice floe. The DOC concentrations in the surface layers and gap water layers of the ISPOL floe were significantly lower than the concentrations in bulk-ice brine or the sackhole brines. All habitats sampled had $[\mathrm{DOC}]_{\mathrm{s}}$ values significantly higher than in the oceanic water when normalised to surface seawater salinity. There was substantial variability in DOC concentrations among samples, either between different ice floes (e.g. 48 and $4439 \mu \mathrm{mol} \mathrm{kg}^{-1}$ in WWOS bulk-ice brine estimates) or within a single ice floe (e.g. 23 to $328 \mu \mathrm{mol} \mathrm{kg}{ }^{-1}$ in ISPOL sackhole brines; Table 1). Overall, the coefficients of variation ranged from 45 to $111 \%$.

TCHO concentrations showed similar patterns to those of DOC. The highest TCHO concentrations were measured in the WWOS ice cores compared to all other sub-habitats (Table 1). The sackhole brine samples from both the ISPOL field experiment and the WWOS 
Table 1. Concentration of dissolved organic carbon (DOC), total carbohydrate (TCHO) and fractionated extracellular polysaccharides $\left(\mathrm{CHO}_{(0-30)}, \mathrm{CHO}_{(30-50)}\right.$ and $\left.\mathrm{CHO}_{(50-70)}\right)$ in $\mu \mathrm{mol} \mathrm{C} \mathrm{kg}{ }^{-1}$ in sea ice habitats, with salinity, temperature $\left({ }^{\circ} \mathrm{C}\right)$, and chlorophyll (chl) a concentrations measured on 2 cruises (ISPOL and WWOS). Values are mean \pm SE, number of samples (in parentheses) and min-max range. The salt enrichment factor (E) represents measured average salinity normalised to a salinity of 35 . [DOC] $]_{S}$ $[\mathrm{TCHO}]_{\mathrm{S}}$ and $[\mathrm{chl} a]_{\mathrm{s}}$ represent average salinity-normalised concentrations. Concentrations in the bulk sea-ice sections were converted according to the calculated fractions of the brine volume per total volume. Carbohydrates were measured against a glucose or glucuronic acid standard and converted into carbon equivalents. \%EPS and \%UA-EPS is the total concentration of extracellular polymeric carbohydrate precipitated in $70 \%$ ethanol compared to the total carbohydrate measurement

\begin{tabular}{|c|c|c|c|c|c|c|}
\hline & $\begin{array}{l}\text { Surface layer } \\
\text { ISPOL }\end{array}$ & $\begin{array}{l}\text { Gap water } \\
\text { ISPOL }\end{array}$ & $\begin{array}{l}\text { Bulk ice brine } \\
\text { ISPOL }\end{array}$ & $\begin{array}{l}\text { Bulk ice brine } \\
\text { WWOS }\end{array}$ & $\begin{array}{l}\text { Sackhole ice brine } \\
\text { ISPOL }\end{array}$ & $\begin{array}{c}\text { Sackhole ice brine } \\
\text { WWOS }\end{array}$ \\
\hline \multicolumn{7}{|l|}{ DOC ( $\left(\mu \mathrm{mol} \mathbf{k g}^{-1}\right)$} \\
\hline $\begin{array}{l}\text { Mean } \pm \mathrm{SE} \\
\text { (n) range }\end{array}$ & $\begin{array}{l}45.3 \pm 3.3 \\
\text { (8) } 36 \text { to } 57\end{array}$ & $\begin{array}{l}139.5 \pm 29.6 \\
\text { (5) } 54 \text { to } 201\end{array}$ & $\begin{array}{c}335.3 \pm 21.3 \\
\text { (50) } 110 \text { to } 754\end{array}$ & $\begin{array}{c}668.9 \pm 97 \\
\text { (59) } 48 \text { to } 4439\end{array}$ & $\begin{array}{c}177.8 \pm 18.9 \\
\text { (21) } 23 \text { to } 328\end{array}$ & $\begin{array}{c}305.8 \pm 18.7 \\
\text { (103) } 114 \text { to } 970\end{array}$ \\
\hline Mean $[\mathrm{DOC}]_{\mathrm{s}}$ & 67.5 & 161.5 & 370.8 & 414.9 & 121.4 & 119.8 \\
\hline \multicolumn{7}{|c|}{ TCHO $\left(\mu \mathrm{mol} \mathrm{C} \mathrm{Gluc}_{\mathbf{k g}^{-1}}\right)$} \\
\hline Mean $\pm \mathrm{SE}$ & $31.0 \pm 5.1$ & $65.8 \pm 24$ & $128.3 \pm 11.8$ & $255.1 \pm 54.7$ & $33.8 \pm 5.5$ & $39.0 \pm 4.5$ \\
\hline (n) range & (8) 4.4 to 48 & (6) 12.7 to 169 & (23) 30 to 223 & (32) 42 to 1794 & (24) 2.3 to 120 & (34) 8.9 to 111 \\
\hline Mean $[\mathrm{TCHO}]_{\mathrm{s}}$ & 45.4 & 76 & 139.2 & 147.2 & 23.6 & 15.4 \\
\hline$\%$ EPS in TCHO & 78 & 68 & 83 & 83 & 79 & 100 \\
\hline \%UA-EPS in TCHO & 25 & 14 & 44 & 48 & 37 & 46 \\
\hline \multicolumn{7}{|c|}{$\mathrm{CHO}_{(0-30)}\left(\mu \mathrm{mol} \mathrm{C}\right.$ Glucose $\left.\mathrm{kg}^{-1}\right)$} \\
\hline $\begin{array}{l}\text { Mean } \pm \text { SE } \\
\text { (n) range }\end{array}$ & $\begin{array}{c}10.9 \pm 1.6 \\
\text { (8) } 4.4 \text { to } 19\end{array}$ & $\begin{array}{c}8.2 \pm 2.2 \\
\text { (5) } 1.5 \text { to } 14\end{array}$ & $\begin{array}{c}55.5 \pm 14 \\
\text { (22) } 7.6 \text { to } 301\end{array}$ & $\begin{array}{c}83 \pm 21 \\
\text { (32) } 0.0 \text { to } 715\end{array}$ & $\begin{array}{c}9.0 \pm 1.1 \\
\text { (24) } 2.0 \text { to } 18\end{array}$ & $\begin{array}{c}14.2 \pm 2.1 \\
\text { (34) } 3.0 \text { to } 63\end{array}$ \\
\hline \multicolumn{7}{|c|}{$\mathrm{CHO}_{(30-50)}\left(\mu \mathrm{mol} \mathrm{C}\right.$ Glucose $\left.\mathrm{kg}^{-1}\right)$} \\
\hline $\begin{array}{l}\text { Mean } \pm \mathrm{SE} \\
\text { (n) range }\end{array}$ & $\begin{array}{c}5.9 \pm 1.3 \\
(8) 0 \text { to } 10\end{array}$ & $\begin{array}{l}5.5 \pm 1.6 \\
\text { (5) } 1.4 \text { to } 9.3\end{array}$ & $\begin{array}{c}34.5 \pm 11 \\
(22) 0 \text { to } 224\end{array}$ & $\begin{array}{c}69 \pm 26 \\
\text { (32) } 0 \text { to } 859\end{array}$ & $\begin{array}{c}9.0 \pm 2 \\
(24) 0 \text { to } 32\end{array}$ & $\begin{array}{c}15 \pm 3 \\
\text { (34) } 0 \text { to } 65\end{array}$ \\
\hline \multicolumn{7}{|c|}{$\mathrm{CHO}_{(50-70)}\left(\mu \mathrm{mol} \mathrm{C}_{\text {Glucose }} \mathrm{kg}^{-1}\right)$} \\
\hline $\begin{array}{l}\text { Mean } \pm \mathrm{SE} \\
\text { (n) range }\end{array}$ & $\begin{array}{c}8.5 \pm 2.4 \\
\text { (8) } 0 \text { to } 19\end{array}$ & $\begin{array}{c}14 \pm 4.3 \\
\text { (5) } 3.2 \text { to } 27\end{array}$ & $\begin{array}{c}30 \pm 7.8 \\
\text { (22) } 0 \text { to } 149\end{array}$ & $\begin{array}{c}58 \pm 11 \\
\text { (32) } 0 \text { to } 280\end{array}$ & $\begin{array}{c}4.6 \pm 1 \\
\text { (24) } 0 \text { to } 18\end{array}$ & $\begin{array}{c}11.0 \pm 2 \\
\text { (34) } 0 \text { to } 45\end{array}$ \\
\hline \multicolumn{7}{|l|}{ Salinity } \\
\hline Mean \pm SE & $23.5 \pm 0.8$ & $29.9 \pm 0.3$ & $32.4 \pm 0.4$ & $58.9 \pm 2.6$ & $51.0 \pm 2.2$ & $92.7 \pm 1.5$ \\
\hline (n) range & (8) 20 to 27 & (7) 29 to 31 & (67) 20 to 37 & (59) 33 to 112 & (29) 29 to 63 & (104) 58 to 130 \\
\hline Enrichment (E) & 0.7 & 0.9 & 0.9 & 1.7 & 1.5 & 2.6 \\
\hline \multicolumn{7}{|l|}{ Temperature $\left({ }^{\circ} \mathbf{C}\right)$} \\
\hline $\begin{array}{l}\text { Mean } \pm \mathrm{SE} \\
\text { (n) range }\end{array}$ & $\begin{array}{c}-1.0 \pm 0.03 \\
(10)-1.2 \text { to }-0.8\end{array}$ & $\begin{array}{c}-1.6 \pm 0.04 \\
\text { (5) }-1.7 \text { to }-1.6\end{array}$ & $\begin{array}{c}-1.8 \pm 0.02 \\
(69)-2.1 \text { to }-1.1\end{array}$ & $\begin{array}{c}-3.4 \pm 0.17 \\
(60)-3.4 \text { to }-1.3\end{array}$ & $\begin{array}{c}-2.7 \pm 0.2 \\
(21)-6.9 \text { to }-1.9\end{array}$ & $\begin{array}{c}-5.6 \pm 0.1 \\
(104)-8.3 \text { to }-3.6\end{array}$ \\
\hline \multicolumn{7}{|l|}{ Chl a $\left(\mu \mathrm{mol} \mathrm{kg}{ }^{-1}\right)$} \\
\hline (n) range & (10) 0.2 to 2.7 & (5) 3.3 to 43 & (67) 0.2 to 1089 & (59) 2.2 to 9645 & - & - \\
\hline Mean $[\mathrm{Chl} a]_{\mathrm{s}}$ & 1.6 & 17.8 & 78.9 & 274.3 & - & - \\
\hline
\end{tabular}

cruise had significantly lower average TCHO concentration than the corresponding brine estimates from bulk sea ice (Table 1). The TCHO concentrations in some of the ISPOL sackhole brine samples were as low as in the surface gap samples (Table 1). Similar to the DOC concentrations noted earlier, the TCHO concentrations also exhibited a large coefficient of variation between 44 and $121 \%$ (Table 1).

Chl a concentrations were extremely heterogeneous between cores and within vertical profiles of individual cores, with highest concentrations in the bottom layers of ice cores (data not shown). Overall, bulk sea-ice cores had the highest concentrations, with the greatest amount of chl a measured in cores from the WWOS cruise (Table 1). Estimates of the salinity-normalised concentrations of chl a showed significantly higher amounts of algal biomass present in the ISPOL gap layer samples and in all bulk sea-ice cores compared to the surface water layers (Table 1). Chl a concentrations in bulk sea-ice samples were significantly correlated with DOC in both the ISPOL and WWOS material (Table 2). There were no significant correlations between chl $a$ and any carbohydrate fractions in the ISPOL samples. In the WWOS bulk sea-ice material (that contained higher levels of biomass and DOC, Table 1), chl a concentrations were significantly correlated with the concentration of EPS-carbohydrates in the fraction $\mathrm{CHO}_{(50-70)}$, uronic acids present in the largest molecular size fraction of EPS $\left(\mathrm{UA}_{0-30}\right)$, and also with non-precipitable carbohydrate $\left(\mathrm{CHO}_{>70}\right)$ (Table 2).

\section{Relationship between DOC, carbohydrate concentra- tions and different carbohydrate fractions}

There was a significant correlation $(\mathrm{r}=0.883, \mathrm{n}=119$, $\mathrm{p}<0.001$ ) between DOC and TCHO concentrations across all environments and sample types (Fig. 2a). 
Table 2. Pearson correlation coefficients between selected chlorophyll (chl) a, dissolved organic carbon (DOC) and total carbohydrate (TCHO) concentrations and salinity, and selected carbohydrate fractions in bulk sea-ice core brines for (a) ISPOL and (b) WWOS cruise data, with sample sizes in parentheses. Values in bold are significant at ${ }^{*} p<0.05,{ }^{* *} p<0.01$ or ${ }^{* * *} p<0.001$; units as in Table $1 . \% \mathrm{CHO}_{(0-30)}$ and $\% \mathrm{CHO}_{(0-50)}$ are the proportion of the total extracellular polymeric substances (EPS)carbohydrate isolated using a 30 or $50 \%$ alcohol solution. Note that $\mathrm{CHO}_{(50-70)}$ replaces $\mathrm{CHO}_{(0-30)}$ in (b)

\begin{tabular}{|c|c|c|c|c|c|c|c|c|}
\hline a) IPSOL & DOC & TCHO & Salinity & $\mathrm{CHO}_{(0-30)}$ & $\mathrm{CHO}_{(>70)}$ & $\mathrm{UA}_{(0-30)}$ & $\% \mathrm{CHO}_{(0-30)}$ & $\% \mathrm{CHO}_{(0-50)}$ \\
\hline Chl a & $\begin{array}{c}\mathbf{0 . 3 0 5}{ }^{* *} \\
(67)\end{array}$ & $\begin{array}{c}0.251 \\
(19)\end{array}$ & $\begin{array}{c}0.086 \\
(67)\end{array}$ & $\begin{array}{c}0.001 \\
(19)\end{array}$ & $\begin{array}{c}0.231 \\
(19)\end{array}$ & $\begin{array}{c}-0.103 \\
(19)\end{array}$ & $\begin{array}{c}0.380 \\
(19)\end{array}$ & $\begin{array}{c}-0.182 \\
(19)\end{array}$ \\
\hline DOC & & $\begin{array}{c}\mathbf{0 . 5 7 9} \\
(19)\end{array}$ & $\begin{array}{c}-\mathbf{0 . 3 8 9}^{* *} \\
(67)\end{array}$ & $\begin{array}{c}\mathbf{0 . 3 3 4}{ }^{* *} \\
(19)\end{array}$ & $\begin{array}{c}0.229 \\
(19)\end{array}$ & $\begin{array}{c}-0.084 \\
(19)\end{array}$ & $\begin{array}{c}0.178 \\
(19)\end{array}$ & $\begin{array}{c}-0.205 \\
(19)\end{array}$ \\
\hline TCHO & & & $\begin{array}{c}0.176 \\
(67)\end{array}$ & $\begin{array}{c}\mathbf{0 . 4 8 4}^{*} \\
(19)\end{array}$ & $\begin{array}{c}\mathbf{0 . 4 2 9}^{*} \\
(19)\end{array}$ & $\begin{array}{c}0.304 \\
(19)\end{array}$ & $\begin{array}{c}0.272 \\
(19)\end{array}$ & $\begin{array}{c}-0.212 \\
(19)\end{array}$ \\
\hline b) WWOS & DOC & TCHO & Salinity & $\mathrm{CHO}_{(50-70)}$ & $\mathrm{CHO}_{(>70)}$ & $\mathrm{UA}_{(0-30)}$ & $\% \mathrm{CHO}_{(0-30)}$ & $\% \mathrm{CHO}_{(0-50)}$ \\
\hline Chl a & $\begin{array}{c}\mathbf{0 . 4 3 0} 0^{* * *} \\
(71)\end{array}$ & $\begin{array}{c}0.225 \\
(34)\end{array}$ & $\begin{array}{c}-0.164 \\
(71)\end{array}$ & $\begin{array}{c}\mathbf{0 . 6 4 6}^{\text {****}} \\
(34)\end{array}$ & $\begin{array}{c}\mathbf{0 . 3 8 0}^{*} \\
(34)\end{array}$ & $\begin{array}{c}\mathbf{0 . 8 1 8} \\
(34)\end{array}$ & $\begin{array}{c}-0.286^{*} \\
(34)\end{array}$ & $\begin{array}{c}-\mathbf{0 . 3 3 1}^{\text {** }} \\
(34)\end{array}$ \\
\hline DOC & & $\begin{array}{c}\mathbf{0 . 9 1 6}^{* * *} \\
(34)\end{array}$ & $\begin{array}{c}-0.078 \\
(71)\end{array}$ & $\begin{array}{c}\mathbf{0 . 3 6 3}^{* *} \\
(71)\end{array}$ & $\begin{array}{c}\mathbf{0 . 8 0 0} \\
(71)\end{array}$ & $\begin{array}{c}\mathbf{0 . 7 6 4} 4^{* * *} \\
(34)\end{array}$ & $\begin{array}{c}-0.186 \\
(34)\end{array}$ & $\begin{array}{c}0.145 \\
(34)\end{array}$ \\
\hline TCHO & & & $\begin{array}{c}-0.201 \\
(71)\end{array}$ & $\begin{array}{c}0.797^{* * *} \\
(34)\end{array}$ & $\begin{array}{c}\mathbf{0 . 4 4 7}^{* *} \\
(34)\end{array}$ & $\begin{array}{c}\mathbf{0 . 4 4 6}^{* *} \\
(34)\end{array}$ & $\begin{array}{c}-0.443^{* *} \\
(34)\end{array}$ & $\begin{array}{c}-0.427^{* *} \\
(34)\end{array}$ \\
\hline
\end{tabular}
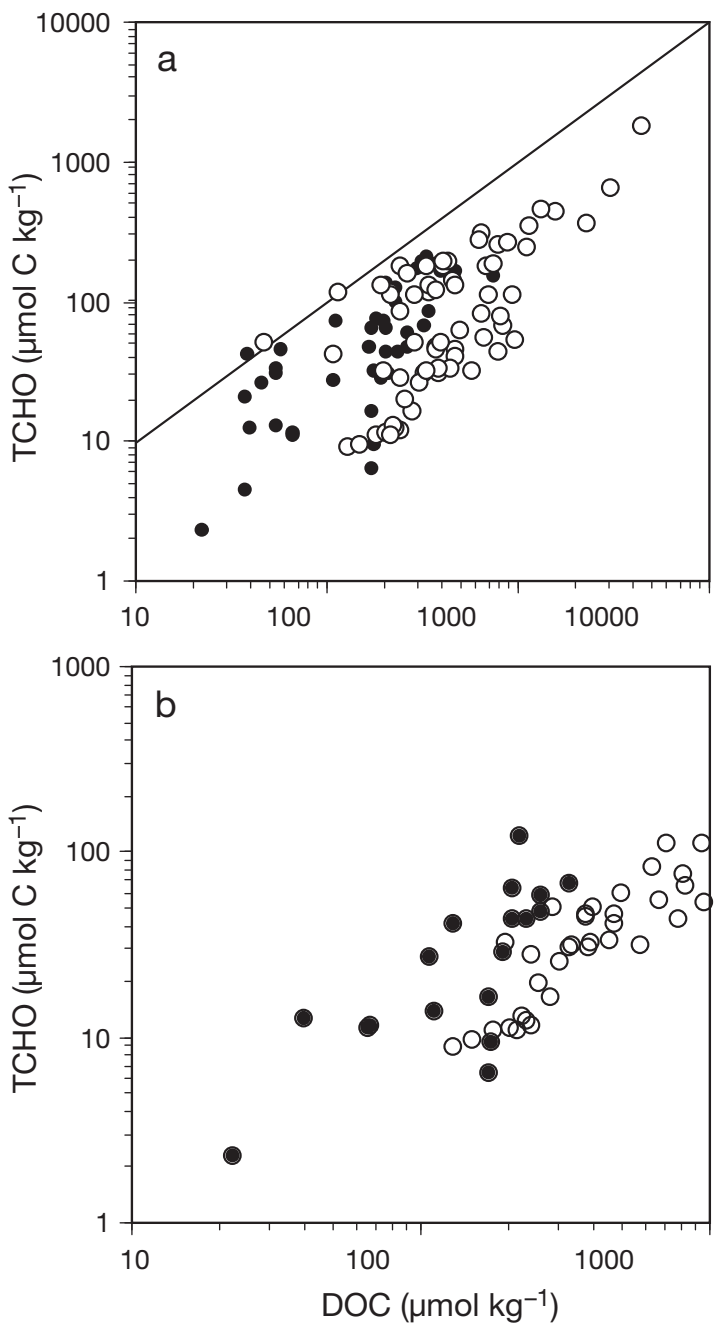

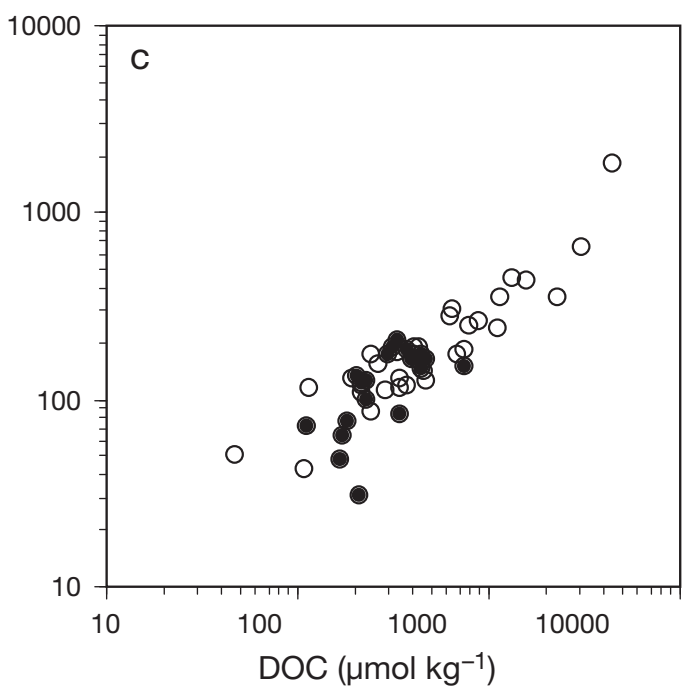

Fig. 2. Correlation of dissolved organic carbon (DOC) and total carbohydrates (TCHO) (a) for all samples including sackhole brine, bulk sea-ice, surface feature and gap water samples, (b) in the sackhole brines, and (c) in the bulk sea-ice samples. $\bullet=$ ISPOL data; $O=$ WWOS data. Line in (a) designates a 1:1 ratio of TCHO:DOC 
However, this general relationship conceals some major differences in the relative contribution of TCHOcarbon to the total DOC pool in different sea ice components. Within the sackhole brines, DOC and TCHO were significantly $(\mathrm{p}<0.001)$ correlated $(\mathrm{r}=0.81$ and 0.66 for WWOS and ISPOL respectively, Fig. $2 \mathrm{~b}$ ), but TCHO (expressed in terms of carbon) in the sackhole brines only accounted for between 10 and $20 \%$ of the DOC concentration (Fig. 3). There were significant correlations between TCHO and DOC in all bulk seaice samples (Table 2), with a very close correlation $(\mathrm{r}=$ 0.916) in the WWOS samples. In the bulk sea-ice brines, TCHO-carbon accounted for approximately 43 and $39 \%$ (ISPOL and WWOS, respectively) of the DOC pool (Fig. 3). DOC and TCHO were not correlated in the gap layer and surface layer ISPOL samples, even though in the surface layer, TCHO-carbon was $55.8 \%$ of the DOC, and in some samples equivalent to $100 \%$ of the DOC (Fig. 3). In comparison, TCHO-carbon in the surface oceanic water was equivalent to 7 and $9 \%$ of the DOC ( $\mathrm{n}=2$, ISPOL cruise), indicating a significant net production of TCHO in sea ice. Both the concentration of TCHO and the TCHO:DOC ratio determined in sackhole brines were significantly lower than those in bulk sea-ice brine estimates and those determined in gap waters (Table 1, Fig. 3).

The concentrations of polysaccharide material (i.e. EPS, cf. Decho 1990, Underwood \& Paterson 2003) were determined by precipitation of the TCHO samples in $70 \%$ alcohol $\mathrm{CHO}_{(0-70)}$. Concentrations of polysaccharide generally reflected the patterns seen for TCHO (Fig. 4a, Table 1): The highest molecular weight

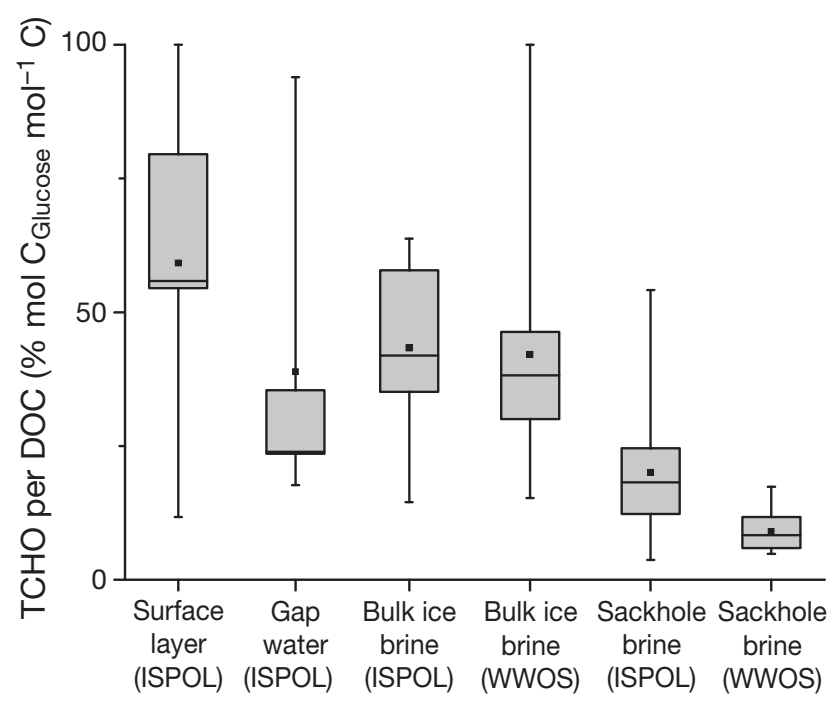

Fig. 3. Contribution of total carbohydrates (TCHO) to dissolved organic carbon (DOC) in different sea-ice types collected during ISPOL and WWOS cruises. Boxes: median and 25/75 percentiles; bars: minima and maxima; filled squares: mean
EPS-carbohydrate fraction $\left(\mathrm{CHO}_{(0-30)}\right.$, Fig. 1), the LMW EPS-carbohydrate fraction $\left(\mathrm{CHO}_{(50-70)}\right)$ and the sum of the concentrations of the $\mathrm{CHO}_{(0-30)}, \mathrm{CHO}_{(30-50)}$ and $\mathrm{CHO}_{(50-70)}$ EPS fractions, i.e. $\mathrm{CHO}_{(0-70)}$, exhibited concentrations that were significantly higher in the bulk sea-ice brines than in the sackhole brines, surface layer and gap layer samples (Table 1). Overall, EPS accounted for $>83 \%$ of the TCHO in the bulk seaice samples, and up to $100 \%$ in the WWOS brines (Table 1).

Fractionation of these EPS into 3 solubility categories revealed that the HMW carbohydrates $\left(\mathrm{CHO}_{(0-30)}\right)$ were of major importance, contributing up to $100 \%$ in some individual samples and always being the largest EPS fraction in all sample types except the gap waters (Fig. $4 \mathrm{a}$, Table 1). The $\mathrm{CHO}_{(50-70)}$ was the smallest size fraction of the EPS-carbohydrates in all bulk sea ice and sackhole brines but represented the largest fraction in the gap waters (Fig. 4a, Table 1). In the ISPOL bulk sea-ice samples, concentrations of $\mathrm{CHO}_{0-30}$ and non-polymeric TCHO (i.e. non-precipitating in $70 \%$ ethanol, $\mathrm{CHO}_{>70}$ ) were correlated with $\mathrm{TCHO}$, but there were no significant correlations with chl $a$. (Table 2a). In contrast, in the WWOS bulk sea-ice cores, both chl $a$ and TCHO were significantly correlated with the concentrations of the smaller EPS $\left(\mathrm{CHO}_{(50-70)}\right)$ and non-polymeric TCHO $\left(\mathrm{CHO}_{>70}\right)$ and negatively correlated with the percentage of EPS in the most insoluble fractions ( $\% \mathrm{CHO}_{0-30}$ and $\% \mathrm{CHO}_{0-50}$, Table 2, Fig. 4a).

Uronic acids contributed a substantial proportion of the TCHO in the bulk sea-ice samples and in the sackhole brines (between 37 and $48 \%$, Table 1). Significantly lower uronic acid concentrations and contributions to the TCHO pool were found in the gap waters and surface layers (14 and $25 \%$ respectively, Table 1). The relative distribution of uronic acids in the different EPS solubility fractions was similar to that of the neutral carbohydrates (compare Fig. $4 a$ \& b), with the exceptions of the ISPOL bulk sea-ice and sackhole brines, where the HMW uronic acids $\left(\mathrm{UA}_{(0-30)}\right)$ were dominant, while the LMW uronic acids $\left(\mathrm{UA}_{(50-70)}\right)$ dominated in the gap water samples (Fig. 4b). The concentrations of $\mathrm{UA}_{(0-30)}$ were significantly correlated with chl $a$ in the WWOS bulk core samples (Table 2).

\section{Seasonality and regional heterogeneity}

Variability of DOC and TCHO concentrations and composition (i.e. solubility fractionation) was high between the different ice habitats, with significant variability in all measured variables within comparable systems (between 1 and 2 orders of magnitude) (Table 1, Fig. 5a). The ranges of DOC and TCHO concentrations measured within the ISPOL ice floe during 

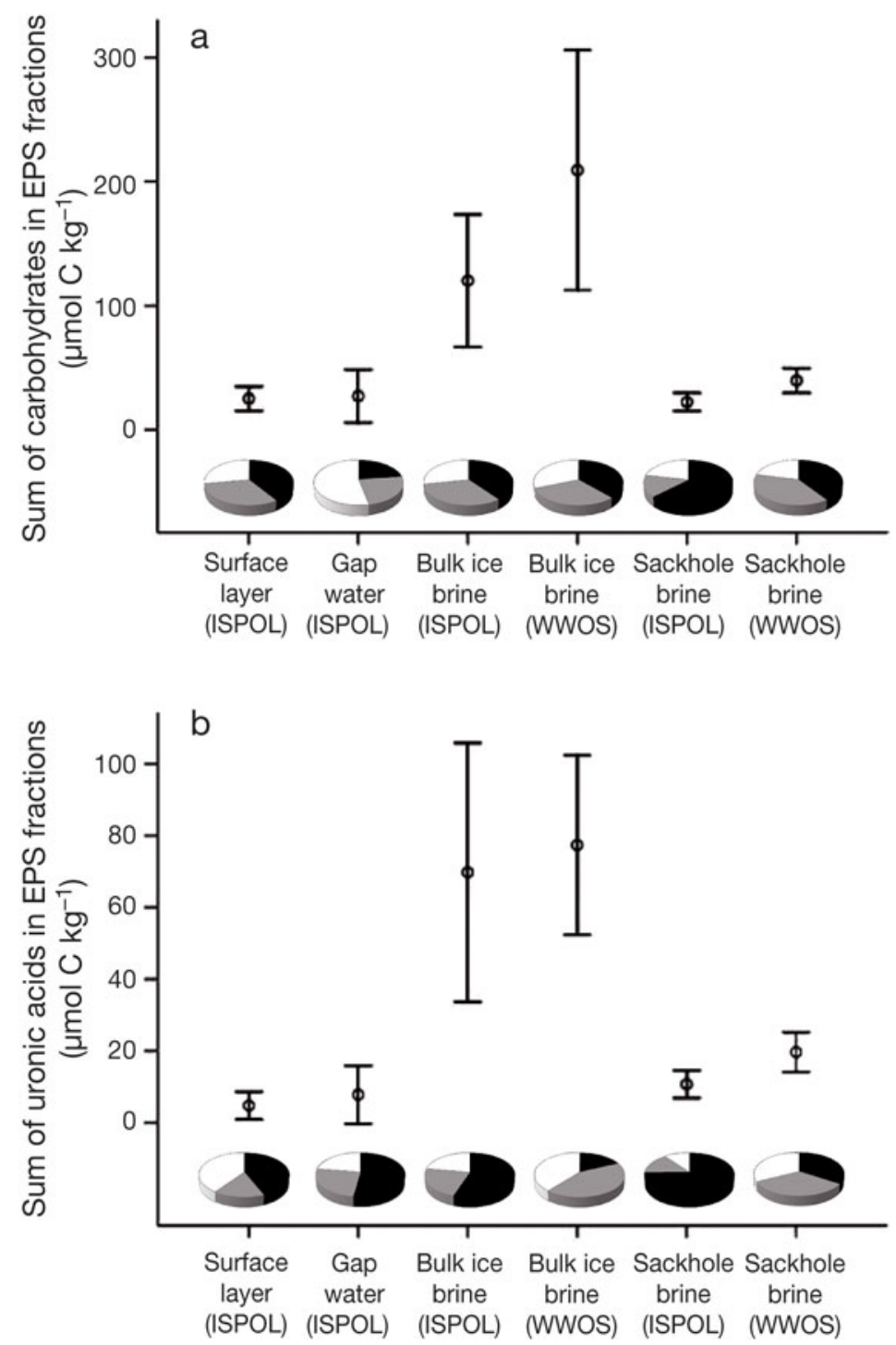

Fig. 4. Contributions of polymers with different molecular weight (cf. Fig. 2) to (a) the carbohydrate pool determined according to Dubois et al. (1956) and (b) the uronic acid pool. Bars represent the average and $95 \% \mathrm{CI}$ of the sum of $\mathrm{CHO}_{(0-30)}, \mathrm{CHO}_{(30-50)}, \mathrm{CHO}_{(50-70)}$ or $\mathrm{UA}_{(0-30)}$, $\mathrm{UA}_{(30-50)}, \mathrm{UA}_{(50-70)}$, respectively. Pies represent the contribution of each fraction, where black: $\mathrm{CHO}_{(0-30)}$ or $\mathrm{UA}_{(0-30)}$; grey: $\mathrm{CHO}_{(30-50)}$ or $\mathrm{UA}_{(30-50)}$; white: $\mathrm{CHO}_{(50-70)}$ or $\mathrm{UA}_{(50-70)}$. See Fig. 1 for extracellular polymeric substances (EPS) nomenclature and structural complexity; structural complexity increases from $\mathrm{CHO}_{(50-70)}$ (white) to $\mathrm{CHO}_{(0-30)}$ (black)

the 30 d observation period in the early summer 2004 were equivalent to those observed in different WWOS ice floes in early spring 2006, which were several hundred miles apart (Fig. 5a). The highest DOC and TCHO concentrations were observed in the samples of 2 distant ice floes sampled on 26 September 2006 at $61^{\circ} 11.07^{\prime} \mathrm{S}$ and $48^{\circ} 54.11^{\prime} \mathrm{W}$ and on 13 October 2006 at $63^{\circ} 51.82^{\prime} \mathrm{S}$ and $54^{\circ} 9.17^{\prime} \mathrm{W}$ (Fig. 5a). The ISPOL samples represented late spring to summer ice conditions (December), and there were seasonal differences in temperature and salinity between the ISPOL samples and the WWOS samples that were sampled during the late winter to spring transition (September to October; Table 1). However, although there was a significant negative correlation between DOC and salinity in the ISPOL cores, there was no indication of any strong salinity or temperature drivers in the data. The proportions of the most insoluble EPS fractions $\left(\% \mathrm{CHO}_{(0-30)}\right.$ or $\mathrm{CHO}_{(50-70)}$ to $\left.\mathrm{TCHO}\right)$ did not exhibit a discernible pattern with temperature and were highly variable across the sea ice temperature spectrum investigated here $\left(-8\right.$ to $0^{\circ} \mathrm{C}$; Fig. 5b). It is likely that any pattern due to seasonality reflected in the temperature extremes of the data is masked by the high heterogeneity of the DOC and carbohydrate distribution between and within the different ice floes.

\section{Monosaccharide composition of EPS}

We found statistically significant differences in the relative contribution of the 8 different monosaccharides present in the TCHO fraction between bulk sea-ice brines, gap water, surface slush and open water samples (Table 3). Gap water and surface layer TCHO had similar monosaccharide profiles, consisting predominantly of glucose $(50+\%)$, with xylose, mannose and galactose as the other main monosaccharides (Table 3). There was relatively less mannose in gap water and surface layer samples compared to sackhole brines and bulk sea-ice brines. Galactose and glucose had significantly higher relative abundances than in the bulk sea-ice brines and sackhole brines, respectively. There were significant differences in the relative monosaccharide composition of $\mathrm{TCHO}$ between the sackhole and bulk sea-ice brines (Table 3). The sackhole brines had a more uniform distribution of monosaccharides, with glucose, galactose, mannose and xylose being the dominant sugars, and rhamnose and fucose contributing between 5 and $9 \%$. In comparison, the dominant monosaccharide in EPS of bulk sea brines was glucose, contributing $>50 \%$ in all core sections (Table 3). Mannose and xylose were found in a similar relative proportion to each other in both sackhole and bulk sea-ice brines, whereas there was proportionally more galactose, rhamnose and fucose in the sackhole brines. ISPOL sackhole brines and bulk sea-ice brines were enriched in xylose relative to the WWOS samples (Table 3).

The monosaccharide composition of the sackhole brine fractions differed from the sackhole TCHO pro- 

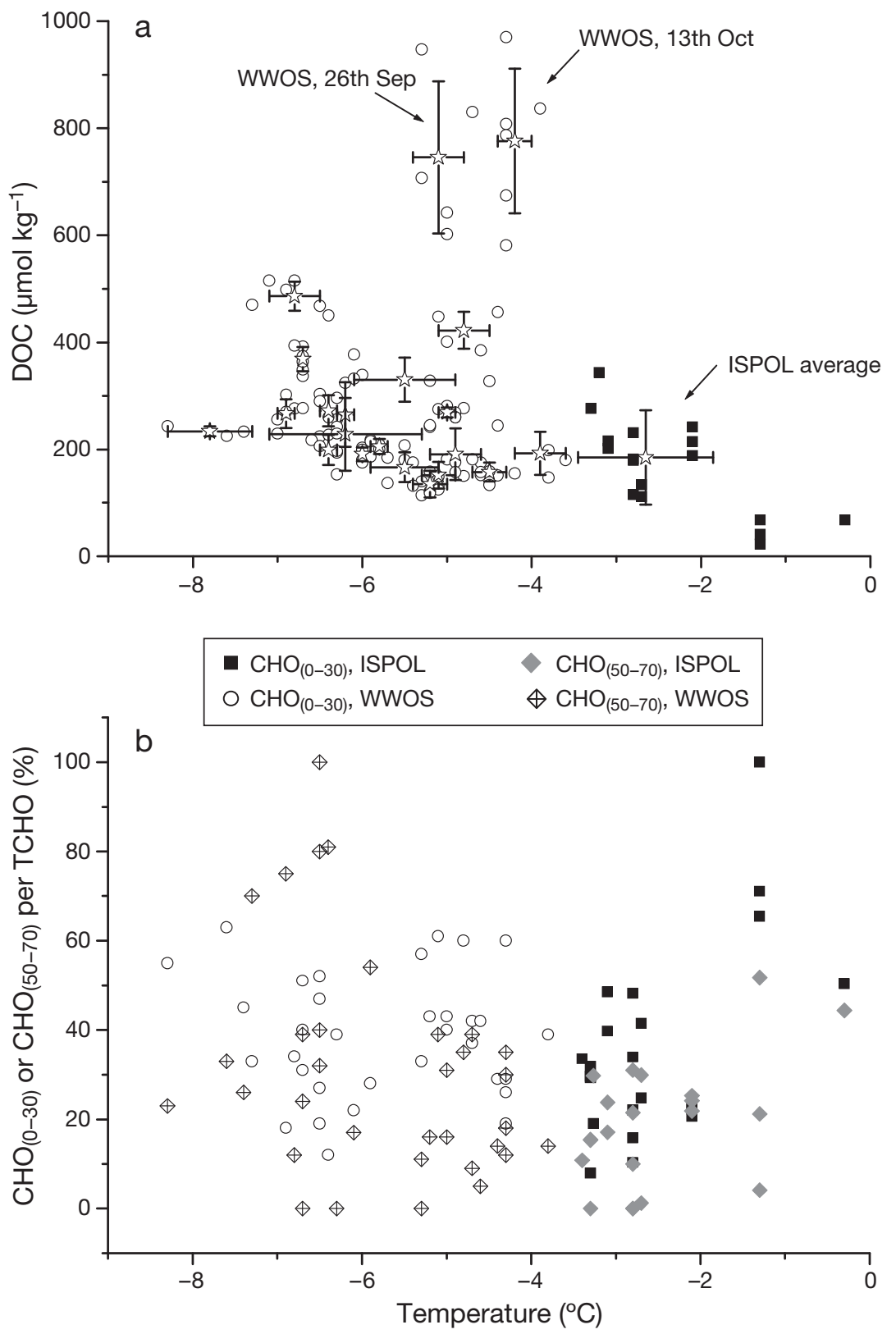

Fig. 5. Seasonal heterogeneity of (a) DOC ( $\mathbf{\square} 2004$ ISPOL data; O: 2006 WWOS data) and (b) extracellular polymeric substance (EPS) size fractions $\left(\mathrm{CHO}_{(0-30)}\right.$ and $\left.\mathrm{CHO}_{(50-70)}\right)$ to total carbohydrates (TCHO) in the sackhole brines. Markers (t) and related error bars in (a) represent means and SD for the distinct drilling sites on distinct ice floes. Similar levels of heterogeneity were present when comparing concentrations against salinity (not shown)

file for both WWOS and ISPOL samples (Table 4). All fractions $\left(\mathrm{CHO}_{(0-30)}, \mathrm{CHO}_{(0-50)}, \mathrm{CHO}_{(0-70)}\right)$ were enriched in rhamnose and fucose compared to the TCHO profile (Table 4). This enrichment was particularly large in the ISPOL $\mathrm{CHO}_{(0-70)}$ fraction. Xylose was enriched in the $\mathrm{CHO}_{(0-30)}$ and $\mathrm{CHO}_{(0-50)}$ and also had relatively more galactose and less glucose (Table 4) than the corresponding TCHO profiles (Table 3).
There was also a marked increase in the relative abundance of rhamnose and fucose in the bulk sea-ice brine EPS fractions compared to the corresponding TCHO profiles (Table 4). Fractionation of TCHO present in bulk sea-ice core samples also resulted in a decrease in the relative importance of glucose from approximately $50 \%$ of the total monosaccharides present in the unfractionated samples to between 24 and $30 \%$ of total monosaccharides in the WWOS samples, and a smaller decrease in the ISPOL samples (40 to $50 \%$ ). The xylose content of the fractions was higher than in the bulk TCHO, with relatively more xylose in the least soluble EPS fraction $\left(\mathrm{CHO}_{(0-30)}\right)$ in both WWOS and ISPOL samples (Table 4). The significantly higher arabinose content in the sackhole compared to the bulk seaice TCHO was not reflected in the profiles of the fractionated EPS, particularly in the WWOS samples.

\section{Ice core profiles}

Relatively complete profiles for $\mathrm{TCHO}$ and uronic acids were obtained from 2 ice cores, core A (9 September 2006, Fig. 6a) and core B (26 September 2006, Fig. 6b) in the WWOS cruise. Detailed size fractionation of EPS and monosaccharide analysis for core A are presented in Fig. 7. There was an increase in ice $t$ from $-5^{\circ} \mathrm{C}$ in the upper $10 \mathrm{~cm}$ of the ice column to approx. $-2^{\circ} \mathrm{C}$ in the bottom ice layers. Concentrations of chl a increased away from the surface layers, although the chl a maxima were not necessarily in the bottom-most core section. Core B had an order of magnitude higher concentration of chl $a$ in its upper sections, increasing with depth, but with an abrupt transition, and the bottom $40 \mathrm{~cm}$ portion of core B contained almost no chl a (Fig. 6 a,b). The DOC and TCHO concentrations were positively correlated $(\mathrm{r}=$ 0.877, $\mathrm{p}<0.001, \mathrm{n}=20$ ), with TCHO-carbon accounting for $54 \%$ of the DOC on average. DOC was highest within the upper sections of cores A and B. DOC and chl a concentrations were not correlated in either core. The \% contribution of TCHO carbon to the total DOC decreased with increasing DOC concentration $(\mathrm{r}=-0.69, \mathrm{p}<0.001, \mathrm{n}=20)$. Overall, the proportion of the TCHO that consisted of $\mathrm{CHO}_{(0-70)}$ decreased with increasing chl a concentrations $(\mathrm{r}=-0.50, \mathrm{p}<$ 
Table 3. Average contribution (mean \% [weight] and SE) to total analysed monosaccharides (determined by gas chromatographymass spectrometry) in unfractionated (total carbohydrate, TCHO) samples in surface features, sea ice brines and sea ice cores collected during 2 cruises (WWOS and ISPOL). nd: not detected

\begin{tabular}{|lcccccccc}
\hline Sample type & Rhamnose & Fucose & Ribose & Arabinose & Xylose & Mannose & Galactose & Glucose \\
\hline Open water (n=4) & nd & nd & $1.0 \pm 1.0$ & $0.6 \pm 0.6$ & $24.4 \pm 3.0$ & $15.9 \pm 9.3$ & $1.3 \pm 1.1$ & $56.9 \pm 7.8$ \\
Surface layer (n=7) & $0.4 \pm 0.4$ & $0.5 \pm 0.5$ & $0.2 \pm 0.2$ & $1.2 \pm 0.2$ & $16.0 \pm 3.4$ & $11.5 \pm 0.9$ & $9.0 \pm 1.7$ & $61.6 \pm 4.1$ \\
Gap water (n = 10) & $0.1 \pm 0.1$ & nd & $0.2 \pm 0.2$ & $2.1 \pm 1.3$ & $21.5 \pm 5.2$ & $17.9 \pm 3.6$ & $11.5 \pm 2.8$ & $51.8 \pm 4.6$ \\
Sackhole brine & & & & & & & \\
WWOS (n=31) & $8.7 \pm 1.3$ & $7.8 \pm 1.2$ & $0.8 \pm 0.1$ & $2.7 \pm 0.6$ & $12.2 \pm 0.9$ & $25.8 \pm 2.4$ & $9.8 \pm 1.0$ & $32.1 \pm 4.5$ \\
ISPOL (n=10) & $6.5 \pm 2.3$ & $5.0 \pm 1.7$ & $4.5 \pm 1.5$ & $1.7 \pm 0.5$ & $21.4 \pm 2.3$ & $24.1 \pm 3.2$ & $13.8 \pm 1.2$ & $23.1 \pm 3.5$ \\
Bulk ice core & & & & & & & \\
WWOS (n=31) & $0.8 \pm 0.2$ & $1.3 \pm 0.3$ & $0.6 \pm 0.1$ & $0.7 \pm 0.2$ & $11.4 \pm 0.8$ & $28.3 \pm 2.5$ & $5.8 \pm 0.5$ & $51.3 \pm 3.2$ \\
ISPOL (n=13) & nd & nd & $1.8 \pm 0.3$ & $0.7 \pm 0.4$ & $15.0 \pm 2.2$ & $22.4 \pm 3.6$ & $5.9 \pm 1.2$ & $54.3 \pm 6.2$ \\
\hline
\end{tabular}

Table 4. Average contribution (mean \% [weight] and SE) to total analysed monosaccharides (determined by gas chromatographymass spectrometry) in fractionated (CHO) samples in sea ice brines and in sea ice cores from the Weddell Sea (samples from 4 ISPOL and 6 WWOS sites are included, with 1 complete core from ISPOL and 1 from WWOS); nd: not detected

\begin{tabular}{|c|c|c|c|c|c|c|c|c|}
\hline & Rhamnose & Fucose & Ribose & Arabinose & Xylose & Mannose & Galactose & Glucose \\
\hline \multicolumn{9}{|l|}{ Sackhole brine } \\
\hline \multicolumn{9}{|l|}{$\mathrm{CHO}_{(0-30)}$} \\
\hline WWOS $(\mathrm{n}=25)$ & $6.4 \pm 1.0$ & $9.1 \pm 1.7$ & $1.3 \pm 0.4$ & $3.6 \pm 0.9$ & $17.1 \pm 0.9$ & $21.0 \pm 1.7$ & $14.0 \pm 0.8$ & $27.5 \pm 2.9$ \\
\hline ISPOL $(n=10)$ & $0.7 \pm 0.7$ & $0.8 \pm 0.8$ & $1.2 \pm 0.5$ & $1.4 \pm 0.6$ & $28.5 \pm 2.5$ & $15.0 \pm 2.9$ & $17.6 \pm 2.9$ & $34.9 \pm 4.2$ \\
\hline \multicolumn{9}{|l|}{$\mathrm{CHO}_{(0-50)}$} \\
\hline WWOS $(\mathrm{n}=23)$ & $11.1 \pm 1.4$ & $12.7 \pm 1.7$ & $2.0 \pm 0.5$ & $3.8 \pm 0.8$ & $15.0 \pm 1.1$ & $20.3 \pm 2.0$ & $13.2 \pm 0.9$ & $22.0 \pm 2.7$ \\
\hline ISPOL $(\mathrm{n}=10)$ & $4.4 \pm 2.1$ & $3.4 \pm 1.6$ & $1.4 \pm 0.6$ & $2.4 \pm 0.7$ & $24.3 \pm 2.3$ & $17.5 \pm 2.2$ & $21.6 \pm 1.6$ & $24.9 \pm 4.8$ \\
\hline \multicolumn{9}{|l|}{$\mathrm{CHO}_{(0-70)}$} \\
\hline WWOS $(\mathrm{n}=21)$ & $10.8 \pm 1.7$ & $9.2 \pm 1.6$ & $9.8 \pm 1.6$ & $2.8 \pm 0.7$ & $11.1 \pm 1.3$ & $20.7 \pm 2.7$ & $8.3 \pm 1.3$ & $36.0 \pm 7.0$ \\
\hline ISPOL (n = 9) & $12.1 \pm 1.2$ & $10.6 \pm 1.6$ & $1.0 \pm 0.3$ & $3.1 \pm 0.3$ & $17.7 \pm 0.8$ & $21.3 \pm 0.7$ & $18.3 \pm 0.9$ & $15.8 \pm 1.0$ \\
\hline \multicolumn{9}{|l|}{ Bulk ice brine } \\
\hline \multicolumn{9}{|l|}{$\mathrm{CHO}_{(0-30)}$} \\
\hline WWOS $(\mathrm{n}=22)$ & $1.4 \pm 0.7$ & $2.5 \pm 0.9$ & $0.4 \pm 0.2$ & $2.4 \pm 0.9$ & $20.6 \pm 1.0$ & $28.6 \pm 2.1$ & $13.6 \pm 0.9$ & $30.3 \pm 1.8$ \\
\hline ISPOL $(n=13)$ & $0.6 \pm 0.4$ & nd & $4.0 \pm 1.4$ & $1.3 \pm 0.8$ & $33.4 \pm 4.5$ & $10.1 \pm 3.2$ & $8.8 \pm 3.0$ & $41.2 \pm 5.1$ \\
\hline \multicolumn{9}{|l|}{$\mathrm{CHO}_{(0-50)}$} \\
\hline WWOS $(\mathrm{n}=20)$ & $4.5 \pm 0.9$ & $6.0 \pm 1.0$ & $1.1 \pm 0.2$ & $5.1 \pm 1.3$ & $18.0 \pm 1.0$ & $27.5 \pm 2.9$ & $14.0 \pm 1.1$ & $23.8 \pm 2.2$ \\
\hline ISPOL $(\mathrm{n}=14)$ & $0.5 \pm 0.3$ & nd & $3.2 \pm 1.0$ & $0.2 \pm 0.2$ & $25.2 \pm 2.7$ & $12.0 \pm 3.5$ & $8.0 \pm 1.6$ & $50.9 \pm 5.2$ \\
\hline \multicolumn{9}{|l|}{$\mathrm{CHO}_{(0-70)}$} \\
\hline WWOS $(\mathrm{n}=19)$ & $6.2 \pm 1.1$ & $5.7 \pm 0.7$ & $1.4 \pm 0.5$ & $3.6 \pm 1.0$ & $13.7 \pm 0.9$ & $32.3 \pm 2.9$ & $9.3 \pm 1.0$ & $27.7 \pm 2.8$ \\
\hline ISPOL $(\mathrm{n}=14)$ & $0.43 \pm 0.3$ & nd & $6.3 \pm 2.5$ & $0.6 \pm 0.4$ & $24.4 \pm 3.1$ & $13.7 \pm 3.9$ & $9.3 \pm 1.7$ & $45.2 \pm 6.6$ \\
\hline
\end{tabular}

0.05, $\mathrm{n}=20$ ). The uronic acid component of EPS was high in some core sections, for example the upper sections of core A (between 80 and $100 \%$ ), and was often below $50 \%$ in core sections with high chl a concentrations. However, there was no significant correlation between these 2 variables in either core.

Concentrations of the different size fractions of EPS in core A mirrored the TCHO concentrations, with the $\mathrm{CHO}_{(0-30)}$ fraction representing the majority of the TCHO (40 to $55 \%$ ) in most ice layers (Fig. 7). The $\mathrm{CHO}_{(30-50)}$ fraction made up about $25 \%$ on average of the TCHO, with a peak contribution at 40 to $50 \mathrm{~cm}$. The $\mathrm{CHO}_{(50-70)}$ fraction was often negligible, particularly in the upper $30 \mathrm{~cm}$ of the core, but became a significant fraction of the TCHO at 60 to $70 \mathrm{~cm}$ depth below the ice surface and within the bottom ice layer (Fig. 7).
The relative distributions of different monosaccharides in the different carbohydrate fractions varied down core A (Fig. 7b). Within the TCHO fraction (Fig. 7b), there was a significant positive correlation ( $r=0.896, p<0.001)$ between the relative abundance of glucose and $\mathrm{TCHO}$, with maximum relative abundance of glucose and concentration of carbohydrate at $80 \mathrm{~cm}$ depth, and corresponding decreases in the relative abundance of xylose and mannose (both monosaccharides having significant negative correlations with the relative abundance of glucose and concentrations of TCHO). In all precipitated EPS fractions, a number of consistent groupings between the different monosaccharides were evident (Fig. 7b). The relative abundances of rhamnose and fucose were positively correlated with each other in all fractions $(r>0.765, p<0.01)$. 

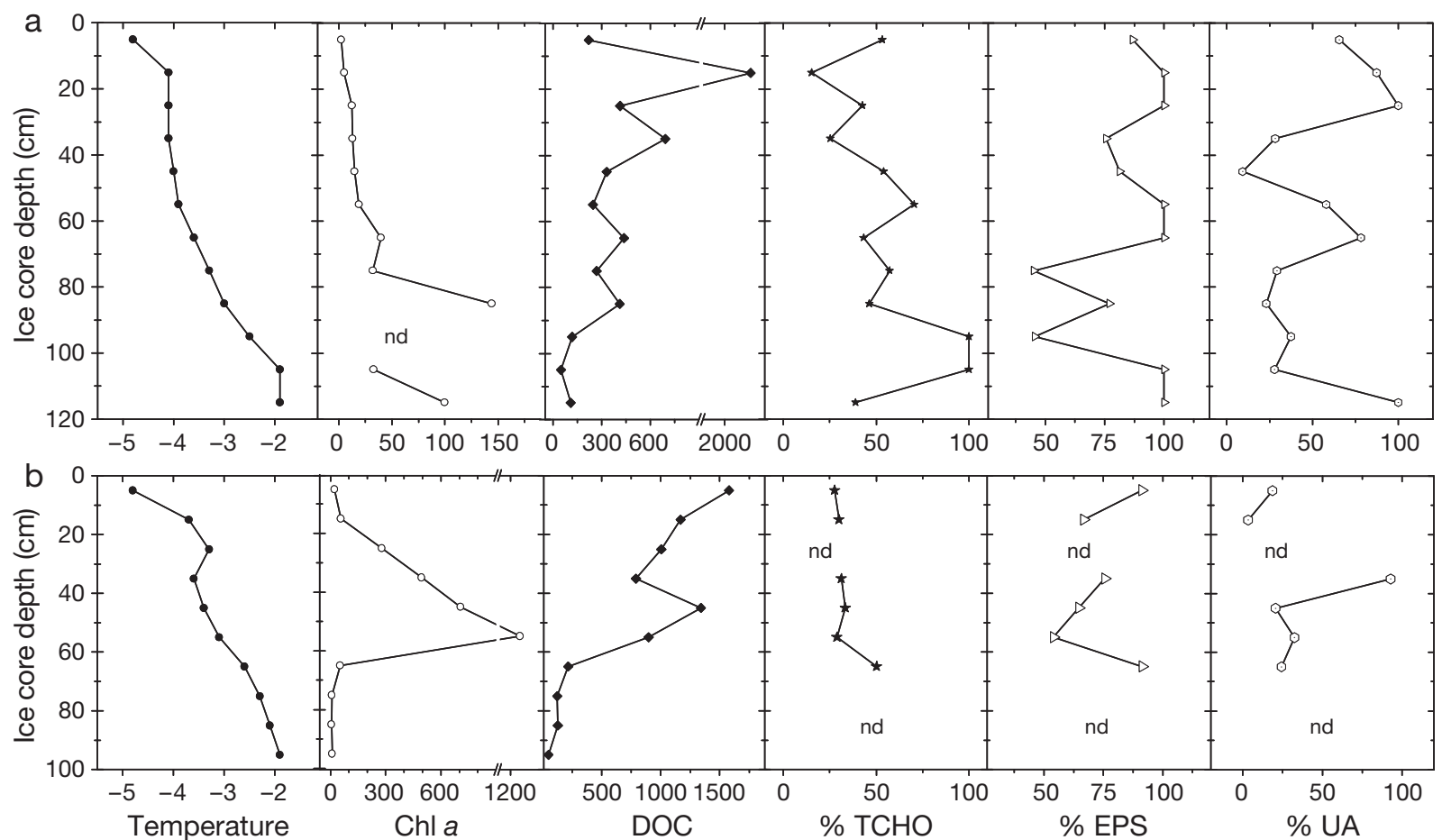

Fig. 6. Ice core depth profiles for temperature $\left({ }^{\circ} \mathrm{C}\right) ;$ chlorophyll (chl) a and dissolved organic carbon (DOC; $\mu \mathrm{mol} \mathrm{kg}{ }^{-1}$ Brine), \% total carbohydrates (TCHO; \% of DOC), \% extracellular polymeric substances (EPS; \% of TCHO) and \% uronic acids (UA; \% of

TCHO) for 2 WWOS ice cores taken on (a) 9 September 2006 (Core A) and (b) 26 September 2006 (Core B). nd: no data
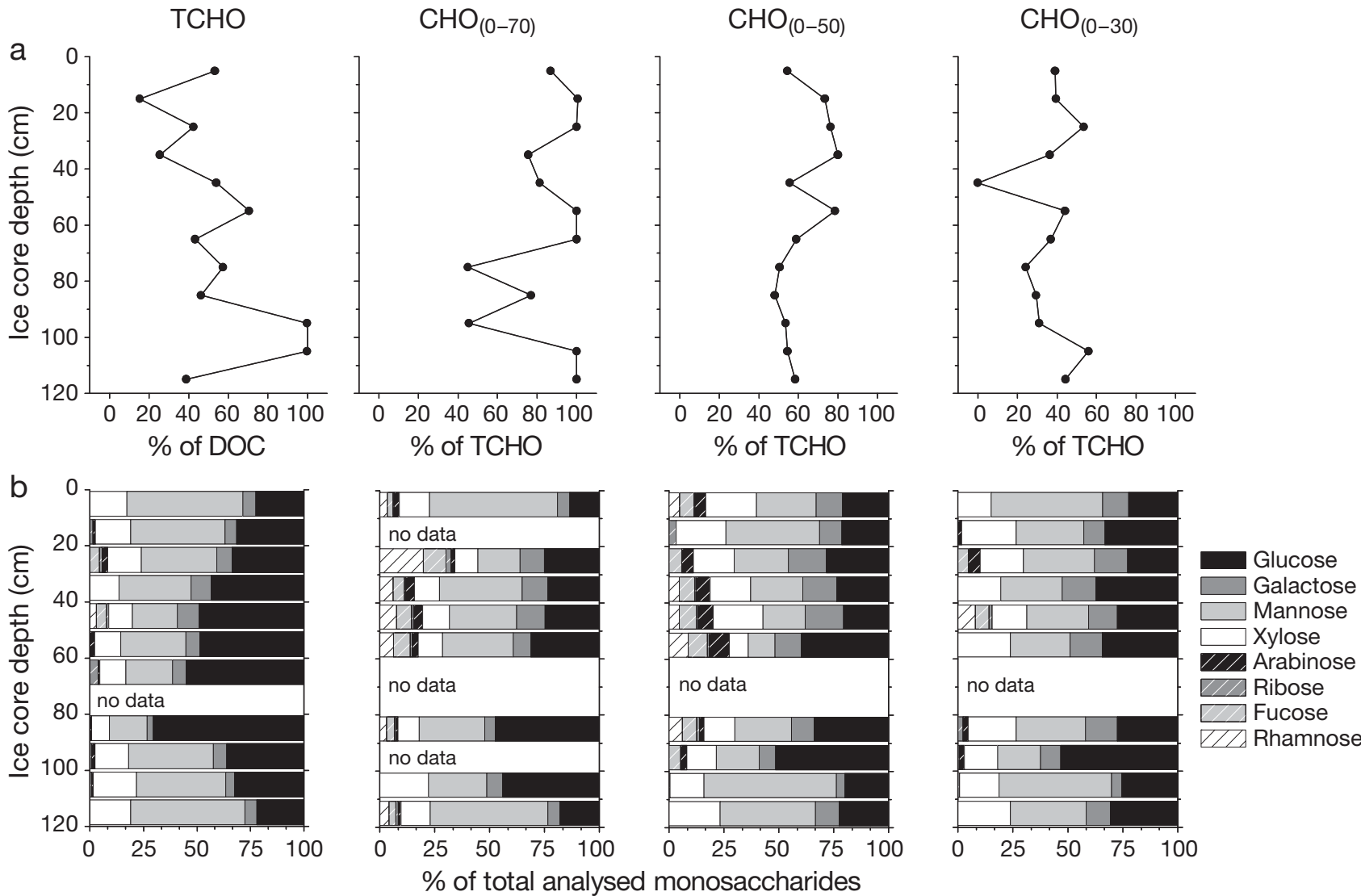

Fig. 7. Ice core depth profile of (a) \% total carbohydrates (TCHO) of dissolved organic carbon (DOC) and the percentage of total carbohydrate present within the $\mathrm{CHO}_{(0-70)}, \mathrm{CHO}_{(0-50)}$ and $\mathrm{CHO}_{(0-30)}$ fractions and (b) the corresponding monosaccharide composition of those fractions from a WWOS core sampled on 9 September 2006 
In the $\mathrm{CHO}_{(0-50)}$ and $\mathrm{CHO}_{(0-70)}$ fractions, the relative abundances of arabinose and galactose were positively correlated ( $\mathrm{r}>0.742, \mathrm{p}<0.05)$. Mannose was negatively correlated with glucose $(\mathrm{r}=-0.646$ or greater, $\mathrm{p}<$ 0.05) in all except the $\mathrm{CHO}_{(0-50)}$ fraction. In the $\mathrm{CHO}_{(0-50)}$ and $\mathrm{CHO}_{(0-70)}$ fractions, the relative abundance of mannose, galactose and arabinose was positively correlated with brine salinity $(p<0.05)$, being highest in the saltier, upper parts of the core. Interestingly, there was a break in these patterns in the bottom $20 \mathrm{~cm}$ of the ice core, where chl a concentrations were high, brine salinity was constant at 33.9, and the concentrations of the smallest EPS size fractions $\left(\mathrm{CHO}_{(50-70)}\right)$ were greatest (Fig. 7a,b).

\section{DISCUSSION}

The concentrations of DOC reported here are within the upper part of the range reported from other sea ice studies from both the Weddell Sea (Herborg et al. 2001, Thomas et al. 2001) and other Antarctic and Arctic regions (Carlson et al. 2000, Thomas et al. 2001, Krembs et al. 2002). Ice concentrations of DOC were more than 3-fold higher than those measured in surface oceanic water in the circumpolar Southern Ocean (Pakulski \& Benner 1994, Kähler et al. 1997, Wedborg et al. 1998, Carlson et al. 2000, Kirchman et al. 2001, Doval et al. 2002, Papadimitriou et al. 2007). Salinitynormalised TCHO concentrations were also significantly elevated in the sea ice samples compared to those from ocean surface water. This shows that there is in situ production of DOC and TCHO production within the sea ice, as well as physical concentration of surface oceanic water DOC during freezing. Given that the greatest DOC and TCHO concentrations were present in the WWOS samples that also supported the highest algal biomass (chl a), there is clearly a coupling between algal activity and DOC and TCHO accumulation in sea ice cores that has not often been reported (Thomas et al. 2001). In contrast to previous findings (Herborg et al. 2001), DOC and TCHO concentrations were highest in the bulk sea-ice brines and lowest in the surface layer and corresponded with the algal standing stock indicated by chl a concentrations (Table 1).

TCHO-carbon comprised a significant proportion of the overall DOC pool in all sea ice samples, generally between 30 to $50 \%$ and, in some cases, $100 \%$ (Fig. 3). These values are generally higher than the relative proportion of carbohydrate to total DOC observed in Arctic and Antarctic seawater (Pakulski \& Benner 1994, Kirchman et al. 2001, Engbrodt \& Kattner 2005, Wang et al. 2006, Myklestad \& Børsheim 2007). This may partly be due in some cases to differing methods used to determine carbohydrate in polar seawater. Where sea ice has been the focus of interest, the contribution of polar sea ice carbohydrate to the DOC pool averages $35 \%$ or less, but ranges from 1 to $99 \%$ (Herborg et al. 2001, Thomas et al. 2001). Some of the non-carbohydrate component of the DOC in the samples would consist of proteins, lipids and free DNA. DON concentrations represented about 5 to $10 \%$ of the DOC (on a molar N:C basis) in the ISPOL and WWOS cruise samples (Norman et al. in press). If Redfield ratios are assumed, then organic nitrogen-containing compounds could contribute 35 to $70 \%$ of the DOC. However, these compounds can also contain carbohydrate, e.g. proteoglycans and aminosugars, so it is not possible to accurately partition the DON and DOC pools in terms of carbon. Thus the majority of the 'unaccounted' DOC-carbon is likely to have a carbohydrate component. Because a dialysis step had to be used to remove salt, LMW material, including carbohydrates $<8 \mathrm{KDa}$, would have been lost before determination of TCHO. It is clear that the sackhole brines and the gap water samples contained a high proportion of LMW carbohydrates, as only 10 to $25 \%$ of the DOC was recovered as TCHO (Fig. 3). The greater proportional recovery of carbohydrate in bulk sea-ice brines $(40+\%$, obtained by melting complete core slices) indicates a greater contribution of HMW (>8 KDa) dissolved carbohydrates in these samples.

\section{Composition of EPS in sea ice}

Fractionation of the TCHO into different EPS fractions indicated that there were high amounts of EPScarbohydrate in the TCHO (between 68 and $100 \%$, Table 1). In the bulk sea-ice cores, $83 \%$ of the TCHO consisted of EPS. Given a $40 \%$ recovery rate of TCHO (Fig. 3), and assuming that $90 \%$ of the DOC is carbohydrate, approximately $36 \%$ of the total dissolved carbohydrate pool in the bulk sea-ice cores would consist of EPS. Studies using the alcian blue method (measuring particulate EPS) have reported substantial concentrations of polymeric material in sea ice, up to $30 \%$ of the particulate carbon pool (Krembs et al. 2002, Meiners et al. 2003) and the equivalent of between 1.4 and $33.5 \%$ (average 13.6\%) of the DOC pool (Meiners et al. 2008). This would suggest that the dissolved and particulate EPS are present in similar concentrations in sea ice. If this was found to be a consistent pattern, it would double the estimates for the overall amount of EPS found in sea ice.

The amount of EPS is generally closely correlated with algal biomass in sediments (Underwood \& Smith 1998) and sea ice (Krembs \& Engel 2001, Riedel et al. 2006, 2008), but there can be additional enrichment in EPS as ice gets older (Riedel et al. 2007, Collins et al. 2008, van der Merwe et al. 2009). One reason sug- 
gested to explain this observation is that EPS production by both algae and bacteria increases as the brine channel environment becomes colder and, therefore, more stressful (Collins et al. 2008). If EPS provides protection against environmental stress via a range of possible structural mechanisms (Krembs \& Engel 2001, Krembs et al. 2002, Tamaru et al. 2005, Krembs \& Deming 2008), then a shift towards EPS with a greater structural potential might be expected in colder or more saline sea ice, in addition to any increases in EPS abundance. EPS could act as a cryoprotectant and a salinity barrier, thus helping modulate the local micro-environment. It is likely that the production of an extracellular matrix of polymers is used by cells to regulate their extracellular water availability. The EPS may also act as a diffusion barrier to keep salts away from but also keep stress protectants, such as glycerol, close to the diatom cell.

In our study, much of the EPS was formed by HMW, less soluble compounds $\left(\mathrm{CHO}_{(0-30)}\right.$ and $\mathrm{CHO}_{(30-50)}$, Fig. $4 \mathrm{a}$ ), with a high concentration of uronic acids present in the HMW EPS fractions (Fig. 4b). All ice core samples had a greater proportion of uronic acids than the gap layer or surface layer samples. Uronic acids contribute to the gelling properties of polymers by providing negative charge and, hence, altering the physical properties of the EPS, i.e. binding and adsorptive capacities, increasing the amount of crossbridging between molecules (Decho 1990, 2000, Nichols et al. 2008). The $\mathrm{CHO}_{(0-30)}$ fraction, particularly in the ISPOL samples, contained more uronic acids than any other EPS fraction investigated here (Fig. 4). The relatively high levels of uronic acid contribution to TCHO (13 to $48 \%$ ) and the other indicators of EPS structural complexity could be indicative of a physiological adaptation of the ice diatom community to extreme conditions of $\mathrm{S}$ and $t$. Diatoms can make such switches in their EPS. Phaeodactylum tricornutum alters its EPS composition, increasing uronic acid, rhamnose, xylose, arabinose and sulphate content (all components promoting polymer structure) when grown in higher salinity media (Abdullahi et al. 2006), and studies on the sea ice diatom isolate Crepidostauros australis (previously called Stauroneis amphioxys) showed that it also changes the composition of its EPS in the same fashion when entering the stationary phase (McConville et al. 1999). Whether such changes are substantial enough to alter the EPS characteristics of whole ice cores remains to be determined. Concentrations of the various EPS fractions were not necessarily correlated with algal biomass, especially in the vertical core profiles. This uncoupling between the producers of EPS and the distribution of EPS could be a result of subsequent ice growth and interactions between EPS and the changing phys- ical matrix of the ice. Brines draining from upper regions of vertical ice profiles as temperatures decrease may carry away LMW EPS leaving more insoluble EPS remaining within the narrowing brine channels. EPS fractions with different solubility and chemical properties will influence the nature of ice crystal formation and potentially become trapped as the ice grows (Krembs \& Deming 2008). Changes in EPS composition are also likely to be influenced by in situ modification of existing EPS by heterotrophic uptake and production by bacteria of a new set of EPS with a different chemical profile (see below).

There was a clear difference between the EPS material determined in sackhole brines and that obtained in bulk sea-ice brine. Sackhole brines most likely represent spatially integrated brine chiefly from the uppermost surface sea ice layers (Papadimitriou et al. 2007). Sackhole brine sampling does not recover all TCHO present in sea ice; approximately 15 to $25 \%$ of the TCHO present in bulk sea-ice core brine is measured in sackhole brines (Table 1). The sackhole brines contained a lower TCHO:DOC, with only a 10 to $20 \%$ yield of TCHO-carbon. The free-draining sackhole brines contain substantial proportions of dissolved carbohydrate smaller than $8 \mathrm{KDa}$ in size, with an underestimation of EPS compared to intact cores. This is not surprising, given that EPS has been shown to attach to the walls of brine channels and encompass cells (Krembs \& Deming 2008) and would not easily drain out of the brine channel matrix. Interestingly, the EPS that was present in the sackhole brines (especially the ISPOL brines) contained proportionally more $\mathrm{CHO}_{(0-30)}$ and a different monosaccharide composition, with lower relative amounts of glucose compared to bulk sea-ice brine samples. Some of the monosaccharides present in higher proportions in these low solubility EPS, such as mannose, xylose and the deoxy sugars rhamnose and fucose, confer greater potential structural and gelling properties on EPS (Wustman et al. 1997, Chiovitti et al. 2003, Abdullahi et al. 2006). These components were generally enriched in the sackhole brine EPS and in the EPS component of the bulk sea-ice TCHO (Table 4).

The EPS material that remained trapped within the ice matrix was higher in glucose content than the sackhole EPS. Although diatoms have been shown to be surrounded by capsules and plugs of EPS (Krembs et al. 2002), the specific composition of those EPS is not known. EPS properties do not only relate to monosaccharide composition but also to branching linkage patterns. Although glucose is often abundant in LMW material, some compositionally simple polymers (i.e. gluco-mannans) can have significant gelling properties. Complex polymer gels can also contain void spaces containing smaller EPS and non-polysaccharide 
carbohydrates (including monsaccharides), and sectioning of ice has shown that particulate EPS can close off brine channels, trapping liquid in the channels. Because the bulk sea-ice core EPS measurements represent the whole spectrum of material present in the ice cores, all of these components will have contributed to the final monosaccharide composition of the TCHO fractions.

In contrast, the TCHO characterised from the gap layer and surface layers in the ISPOL cruise had quite a different monosaccharide profile to that of the ice brines and cores, being dominated by glucose, xylose, mannose and galactose, and lacking in the structural deoxy sugars rhamnose and fucose; this profile was similar to that of EPS produced by diatoms actively growing in estuarine biofilms (Hofmann et al. 2009). Our data suggest that there is an EPS component within the sea ice matrix that contains a range of characteristics (low solubility, high uronic acid content, diverse monosaccharide composition) that could provide a hydrophobic and structured microenvironment. Comparison of such a profile to other studies (Hofmann et al. 2009) would suggest that this type of EPS is not produced by an actively growing algal assemblage. While there is increasing circumstantial evidence for the selective advantages to microbes producing EPS in sea ice environments (Collins et al. 2008, Krembs \& Deming 2008, van der Merwe et al. 2009), detailed physiological work with characteristic sea ice microorganisms is needed to understand the relationship between composition, structure and the putative beneficial properties of EPS for microbes within sea ice habitats.

\section{Modification of EPS in situ}

It appears fairly well established that the majority of EPS present in sea ice is produced by algae (Krembs \& Engel 2001, Meiners et al. 2003, 2008). In the present study, the WWOS samples, with the higher algal biomass, also tended to have higher concentrations of the smaller EPS fractions and non-precipitable $\mathrm{CHO}$ components, indicating that these materials have been produced by autotrophic activity. However, once produced, EPS is subject to transformations due to biological activity. The age of the ice being sampled will therefore, a priori, play a role in determining the amount and properties of EPS. There is a peak in biological activity shortly after ice formation, after which rates of production decline as the ice thickens and conditions become less conducive to microbial activity; this is followed by a second peak during the thaw (Grossmann \& Dieckmann 1994, Riedel et al. 2006, 2008, Collins et al. 2008). During the winter months, material present in the brines becomes entombed, to be slowly modified by the environment and by microbial action. Experimental studies in other systems have shown that freshly produced diatom EPS and other exudates (diatoms are thought to be the major producers of EPS in sea ice, Meiners et al. 2008) are glucose- and galactose-rich, and are utilised rapidly by heterotrophs (McConville et al. 1999, Goto et al. 2001, Haynes et al. 2007, Hofmann et al. 2009), leaving behind more refractory material. Some bacteria seem unable to grow on some types of EPS, while readily growing on others (Hofmann et al. 2009). The ISPOL cores, with low chl a concentrations, showed no relationship between chl $a$ and any carbohydrate fractions, with lower concentrations of DOC and TCHO, but greater proportions of larger EPS. This would suggest that the more easily assimilated DOC had been utilised. There is some evidence to support this in the change in EPS size distribution and monosaccharide profiles within ice cores. In ice cores, the newest ice is at the bottom (where chl a concentrations are highest), although this was not necessarily the site of highest EPS concentration (Figs. 6 \& 7). Overall, in the WWOS ice core brines, where there was higher $\operatorname{chl} a_{\text {, there }}$ was more soluble EPS $\left(\mathrm{CHO}_{(50-70)}\right)$ and non-EPS carbohydrate $\left(\mathrm{CHO}_{(>70)}\right)$ and more glucose, possibly reflecting production of new EPS and other photoassimilates by diatoms, and an older, more recalcitrant EPS (often with a high contribution of uronic acids, Fig. 6) remaining in the colder and more saline brine channels. Higher rates of bacterial activity have been recorded on TEP particles in Arctic sea ice (Meiners et al. 2008), indicating that these EPS flocs act as microbial hotspots akin to the role played by marine snow in the water column. Such activity would make a further contribution to the EPS pool in the brine channel through the production of EPS by these heterotrophic bacteria (Mancuso Nichols et al. 2005, Hofmann et al. 2009). These processes would suggest that as sea ice ages, the nature of the EPS present will change, with a relative increase in biologically recalcitrant polysaccharides and polysaccharides produced by heterotrophic microorganisms, compared to the spectrum of EPS to fresh sea ice containing an active algal assemblage. While the pattern within cores supports this, we could not successfully test this hypothesis on a larger scale, as any potential temporal resolution between cores was masked due to the high spatial heterogeneity of the ISPOL and WWOS data sets. Detailed time course measurements of well-characterised ice over a growing season, with a sampling design suitable to overcome spatial heterogeneity, are needed to investigate the relationship between EPS chemical composition and temporal changes in the microbial populations (Collins et al. 2008). 


\section{CONCLUSIONS}

In the 2 sets of Weddell Sea ice studied, dissolved EPS was a significant proportion of the DOC pool, with the concentrations of EPS in the dissolved fraction in the same order of magnitude as particulate EPS measured in sea ice by other workers. High heterogeneity was a significant feature of the dataset, with no clear patterns in EPS characteristics relating to temperature or salinity, despite different ice provenance between the ISPOL and WWOS cruises. Fractionation of the EPS showed varying patterns of size distribution and composition, buth with a high proportion of low solubility, potentially more complex EPS within ice brines, as well as more soluble EPS and non-EPS carbohydrate fractions associated with higher algal biomass. The different EPS fractions had significant differences in their uronic acid composition, monosaccharide composition and distribution. Much of the dissolved EPS appears to stick within ice cores and is not sampled by sackhole methods. Differences in EPS characteristics within ice cores may reflect the production of complex EPS by microorganisms to promote microbial survival as conditions become harsher, as well as temporal modification by physical or biological mechanisms. To resolve this question a finer scale of spatial sampling or experimental approaches using mesocosms or cultures is required. It would appear that by the end of the polar winter, sea ice does contain substantial concentrations of complex, potentially refractory EPS that will enter the ocean water surface DOC pool during the time of ice melt. The bioavailability of this complex EPS at that stage is not known.

Acknowledgements. This work was funded by NERC (grants NE/D00681/1 and NE/E016251/1), The Royal Society and The Leverhulme Trust. S.F. thanks the Deutsche Forschungsgemeinschaft (DFG) for partial support. We thank the master and crew of the RV 'Polarstern' and helicopter crews for their help in making the sampling possible, as well as many colleagues from the ISPOL and WWOS teams who helped in fieldwork activities. In particular we thank L. Norman, C. Haas, M. Nicolaus, A. Batzke, H. Betts, E. Allhusen, A. Scheltz and R. Thomas. We also acknowledge the anonymous reviewers who provided extremely helpful and constructive comments.

\section{LITERATURE CITED}

Abdullahi AS, Underwood GJC, Gretz MR (2006) Extracellular matrix assembly in diatoms (Bacillariophyceae). V. Environmental effects on polysaccharide synthesis in the model diatom, Phaeodactylum tricornutum. J Phycol 42: 363-378

Ackley SF, Lewis MJ, Fritsen CH, Xie H (2008) Internal melting in Antarctic sea ice: development of "gap layers". Geophys Res Lett 35:L11503, doi:10.1029/2008GL033644
Apoya-Horton MD, Yin L, Underwood GJC, Gretz MR (2006) Movement modalities and responses to environmental changes of the mudflat diatom Cylindrotheca closterium (Bacillariophyceae). J Phycol 42:379-390

- Arrigo KR, van Dijken G, Long M (2008) Coastal Southern Ocean: a strong anthropogenic carbon dioxide sink. Geophys Res Lett 35:L21602, doi: 10.1029/2008GL035624

Aspinall GO (1982). The polysaccharides Vol. 1. Academic Press, New York, NY

Bellinger BJ, Abdullahi AS, Gretz MR, Underwood GJC (2005) Biofilm polymers: relationship between carbohydrate biopolymers from estuarine mudflats and unialgal cultures of benthic diatoms. Aquat Microb Ecol 38: 169-180

Bitter T, Muir HM (1962) A modified uronic acid carbazole reaction. Anal Biochem 4:330-334

Carlson CA, Hansell DA, Peltzer ET, Smith WO (2000) Stocks and dynamics of dissolved and particulate organic matter in the southern Ross Sea, Antarctica. Deep-Sea Res II 47: 3201-3226

Chiovitti AM, Higgins J, Harper RE, Wetherbee R, Bacic A (2003) The complex polysaccharides of the raphid diatom Pinnularia viridis (Bacillariophyceae). J Phycol 39:543-554

Collins RE, Carpenter SD, Deming JW (2008) Spatial heterogeneity and temporal dynamics of particles, bacteria and pEPS in Arctic winter sea ice. J Mar Syst 74:902-917

Cox GFN, Weeks WF (1983) Equations for determining the gas and brine volumes in sea ice samples. J Glaciol 29: 306-316

Decho AW (1990) Microbial exopolymer secretions in ocean environments: their role(s) in food webs and marine processes. Oceanogr Mar Biol Annu Rev 28:73-153

Decho AW (2000) Microbial biofilms in intertidal systems: an overview. Cont Shelf Res 20:1257-1273

Doval MD, Alvarez-Salgado XA, Castro CG, Perez FF (2002) Dissolved organic carbon distributions in the Bransfield and Gerlache Straits, Antarctica. Deep-Sea Res II 49: 663-674

Dubois M, Gilles KA, Hamilton PA, Rebers PA, Smith F (1956) Colorimetric method for determination of sugars and related substances. Anal Chem 28:350-356

Engbrodt R, Kattner G (2005) On the biogeochemistry of dissolved carbohydrates in the Greenland Sea (Arctic). Org Geochem 36:937-948

Evans CA, O'Reilly JE, Thomas JP (1987) A handbook for the measurement of chlorophyll a and primary production. Biological investigations of marine Antarctic systems and stocks (BIOMASS). Texas A\&M University, College Station, TX

Goto N, Mitamura O, Terai H (2001) Biodegradation of photosynthetically produced extracellular organic carbon from intertidal benthic algae. J Exp Mar Biol Ecol 257:73-86

Grossmann S, Dieckmann GS (1994) Bacterial standing stock, activity, and carbon production during formation and growth of sea ice in the Weddell Sea, Antarctica. Appl Environ Microbiol 60:2746-2753

> Haas C, Thomas DN, Bareiss J (2001) Surface properties and processes of perennial Antarctic sea ice in summer. J Glaciol 47:613-625

> Haas C, Nicolaus M, Willmes S, Worby A, Flinspach D (2008) Sea ice and snow thickness and physical properties of an ice floe in the western Weddell Sea and their changes during spring warming. Deep-Sea Res II 55:963-974

> Haynes K, Hofmann TA, Smith CJ, Ball AS, Underwood GJC, Osborn AM (2007) Diatom-derived carbohydrates as factors affecting bacterial community composition in estuarine sediments. Appl Environ Microbiol 73:6112-6124 
Hellmer HH, Haas C, Dieckmann GS, Schröder M (2006) Sea ice feedbacks observed in Western Weddell Sea. EOS Trans Am Geophys Union 87:173-184

Herborg LM, Thomas DN, Kennedy H, Haas C, Dieckmann GS (2001) Dissolved carbohydrates in Antarctic sea ice. Antarct Sci 13:119-125

- Hofmann T, Hanlon ARM, Taylor JD, Ball AS, Osborn AM, Underwood GJC (2009) Dynamics and compositional changes in extracellular carbohydrates in estuarine sediments during degradation. Mar Ecol Prog Ser 379:45-58

Kähler P, Bjornsen PK, Lochte K, Antia A (1997) Dissolved organic matter and its utilization by bacteria during spring in the Southern Ocean. Deep-Sea Res II 44:341-353

Kattner G, Thomas DN, Haas C, Kennedy H, Dieckmann GS (2004) Surface ice and gap layers in Antarctic sea ice: highly productive habitats. Mar Ecol Prog Ser 277:1-12

Kennedy H, Thomas D, Kattner G, Haas C, Dieckmann GS (2002) Particulate organic matter in Antarctic summer sea ice: concentration and stable isotopic composition. Mar Ecol Prog Ser 238:1-13

- Kirchman DL, Meon B, Ducklow HW, Carlson CA, Hansell DA, Steward GF (2001) Glucose fluxes and concentrations of dissolved combined neutral sugars (polysaccharides) in the Ross Sea and polar Front Zone, Antarctica. Deep-Sea Res II 48:4179-4197

Krembs C, Deming J (2008) The role of exopolymers in microbial adaptation to sea-ice. In: Margesin R, Schinner F, Marx JC, Gerday C (eds) Psychrophiles: from biodiversity to biotechnology. Springer Verlag, Berlin, p 247-264

$>$ Krembs C, Engel A (2001) Abundance and variability of microorganisms and transparent exopolymer particles across the ice-water interface of melting first-year sea ice in the Laptev Sea (Arctic). Mar Biol 138:173-185

Krembs C, Mock T, Gradinger R (2001) A mesocosm study of physical-biological interactions in artificial sea ice: effects of brine channel surface evolution and brine movement on algal biomass. Polar Biol 24:356-364

Krembs C, Eicken H, Junge K, Deming JW (2002) High concentrations of exopolymeric substances in Arctic winter sea-ice: implications for the polar ocean carbon cycle and cryoprotection of diatoms. Deep-Sea Res I 49:2163-2181

Lannuzel D, Schoemann V, de Jong J, Chou L, Delille B, Becquevort S, Tison JL (2008) Iron study during a time series in the western Weddell pack ice. Mar Chem 108:85-95

Lemke P (ed) (2009) The expedition ANTARKTIS-XXV11/7 of the research vessel 'Polarstern' in 2006. Rep Polar Res 586: $1-147$

Leppäranta M, Manninen T (1988) The brine and gas content of sea ice with attention to low salinities and high temperatures. Finnish Institute of Marine Research Internal Report 88-2, Helsinki

Mancuso Nichols C, Lardière SG, Bowman JP, Nichols PD, Gibson JAE, Guézennec J (2005) Chemical characterization of exopolysaccharides from Antarctic marine bacteria. Microb Ecol 49:578-589

McConville MJ, Wetherbee R, Bacic A (1999) Subcellular location and composition of the wall and secreted extracellular sulphated polysaccharides/proteoglycans of the diatom Stauroneis amphioxys Gregory. Protoplasma 206: $188-200$

Meiners K, Gradinger R, Fehling J, Citivarese G, Spindler M (2003) Vertical distribution of exopolymer particles in sea ice of the Fram Strait (Arctic) during autumn. Mar Ecol Prog Ser 248:1-13

Meiners K, Krembs C, Gradinger R (2008) Exopolymer particles: microbial hotspots of enhanced bacterial activity in Arctic fast ice (Chukchi Sea). Aquat Microb Ecol 52:
195-207

Meiners KM, Papadimitriou S, Thomas DN, Norman L, Dieckmann GS (2009) Biogeochemical conditions and ice algal photosynthetic parameters in Weddell Sea ice during early spring. Polar Biol 32:1055-1065

> Millero FJ, Poisson A (1981) International one-atmosphere equation of state for seawater. Deep-Sea Res A Oceanogr Res Pap 28:625-629

> Myklestad SM, Børsheim KY (2007) Dynamics of carbohydrates in the Norwegian Sea inferred from monthly profiles collected during 3 years at $66^{\circ} \mathrm{N} 2^{\circ} \mathrm{E}$. Mar Chem 107:475-485

> Nichols PD, Mancuso Nichols CA (2008) Microbial signature lipid profiling and exopolysaccharides: experiences initiated with Professor David C White and transported to Tasmania, Australia. J Microbiol Methods 74:33-46

Norman L, Thomas DN, Stedmon CA, Granskog MA and others (in press) The characteristics of dissolved organic matter (DOM) and chromophoric dissolved organic matter (CDOM) in Antarctic sea ice. Deep-Sea Res II

Pakulski JD, Benner R (1994) Abundance and distribution of dissolved carbohydrates in the ocean. Limnol Oceanogr 39:930-940

Papadimitriou S, Kennedy H, Thomas DN (2004) Rates of organic carbon oxidation in deep sea sediments from the eastern North Atlantic from pore water $\mathrm{O}_{2}$ and $\delta^{13} \mathrm{C}$ of dissolved inorganic carbon profiles. Mar Geol 212:97-111

Papadimitriou S, Thomas DN, Kennedy H, Kuosa H, Krell A, Dieckmann GS (2007) Biogeochemical composition of natural sea ice brines from the Weddell Sea during early austral summer. Limnol Oceanogr 52:1809-1823

> Papadimitriou S, Thomas DN, Kennedy H, Kuosa H, Dieckmann GS (2009) Inorganic carbon removal and isotopic enrichment in Antarctic sea ice gap layers during early austral summer. Mar Ecol Prog Ser 386:15-27

Passow U, Alldredge A (1995) A dye binding assay for the spectrophotometric measurement of transparent exopolymer particles (TEP). Limnol Oceanogr 40:1326-1335

Petrich C, Eicken H (2010) Growth, structure and properties of sea ice. In: Thomas DN, Dieckmann GS (eds) Sea ice, 2nd edn. Wiley-Blackwell, Oxford, p 23-78

Qian J, Mopper K (1996) Automated high-performance, hightemperature combustion total organic carbon analyzer. Anal Chem 68:3090-3097

> Riedel A, Michel C, Gosselin M (2006) Seasonal study of seaice exopolymeric substances on the Mackenzie shelf: implications for transport of sea-ice bacteria and algae. Aquat Microb Ecol 45:195-206

Riedel A, Michel C, Gosselin M, LeBlanc B (2007a) Enrichment of nutrients, exopolymeric substances and microorganisms in newly formed sea ice on the Mackenzie shelf. Mar Ecol Prog Ser 342:55-67

> Riedel A, Michel C, Gosselin M (2007b) Grazing of largesized bacteria by sea-ice heterotrophic protists on the Mackenzie shelf during the winter-spring transition. Aquat Microb Ecol 50:25-38

> Riedel A, Michel C, Gosselin M, LeBlanc B (2008) Winterspring dynamics in sea-ice carbon cycling in the coastal Arctic Ocean. J Mar Syst 74:918-932

Smith DJ, Underwood GJC (1998) Exopolymer production by intertidal epipelic diatoms. Limnol Oceanogr 43:1578-1591

Staats N, Stal LJ, de Winder B, Mur LR (2000) Oxygenic photosynthesis as driving process in exopolysaccharide production of benthic diatoms. Mar Ecol Prog Ser 193: 261-269

Tamaru Y, Takani Y, Yoshida T, Sakamoto T (2005) Crucial role of extracellular polysaccharides in desiccation and 
freezing tolerance in the terrestrial cyanobacterium Nostoc commune. Appl Environ Microbiol 71:7327-7333

Thomas DN, Dieckmann GS (2002) Antarctic sea ice-a habitat for extremophiles. Science 295:641-644

Thomas DN, Dieckmann GS (2010) Sea ice, 2nd edn. WileyBlackwell, Oxford

Thomas DN, Lara RJ, Haas C, Schnack-Schiel SB and others (1998) Biological soup within decaying summer sea ice in the Amundsen Sea, Antarctica. In: Lizotte M, Arrigo K (eds) Antarctic sea ice: biological processes, interactions, and variability. Antarct Res Ser 73:161-171

Thomas DN, Kattner G, Engbrodt R, Giannelli V, Kennedy H, Haas C, Dieckmann GS (2001) Dissolved organic matter in Antarctic sea ice. Ann Glaciol 33:297-303

Underwood GJC, Paterson DM (2003) The importance of extracellular carbohydrate production by marine epipelic diatoms. Adv Bot Res 40:183-240

Underwood GJC, Smith DJ (1998) Predicting epipelic diatom exopolymer concentrations in intertidal sediments from sediment chlorophyll a. Microb Ecol 35:116-125

Underwood GJC, Boulcott M, Raines CA, Waldron K (2004) Environmental effects on exopolymer production by marine

Editorial responsibility: Andrew Brierley, St. Andrews, UK; Hans Heinrich Janssen, Oldendorf/Luhe, Germany benthic diatoms - dynamics, changes in composition and pathways of production. J Phycol 40:293-304

van der Merwe P, Lannuzel D, Mancuso Nichols CA, Meiners $\mathrm{K}$ and others (2009) Biogeochemical observations during the winter-spring transition in East Antarctic sea ice: evidence of iron and exopolysaccharide controls. Mar Chem 115:163-175

Wang D, Henrichs SM, Guo L (2006) Distributions of nutrients, dissolved organic carbon and carbohydrates in the western Arctic Ocean. Cont Shelf Res 26:1654-1667

> Wedborg M, Hoppema M, Skoog A (1998) On the relation between organic and inorganic carbon in the Weddell Sea. J Mar Syst 17:59-76

Wingender J, Neu TR, Flemming HC (1999) Microbial extracellular polymeric substances: characterisation, structures and function. Springer-Verlag, Berlin

Wustman BA, Gretz MR, Hoagland KD (1997) Extracellular matrix assembly in diatoms (Bacillariophyceae) (I. A model of adhesives based on chemical characterization and localization of polysaccharides from the marine diatom Achnanthes longipes and other diatoms). Plant Physiol 113:1059-1069

Submitted: May 18, 2009; Accepted: February 25, 2010 Proofs received from author(s): March 22, 2010 